Canadian Science Publishing

Canadian Journal of Earth Sciences Revue canadienne des sciences de la Terre

\title{
Plate-tectonic evolution of the Earth: bottom-up and top- down mantle circulation
}

\begin{tabular}{|r|l|}
\hline Journal: & Canadian Journal of Earth Sciences \\
\hline Manuscript ID & cjes-2015-0126.R1 \\
\hline Manuscript Type: & Article \\
\hline Date Submitted by the Author: & $22-$ Sep-2015 \\
\hline Complete List of Authors: & $\begin{array}{l}\text { Ernst, W.; Stanford University, Geological Sciences } \\
\text { Sleep, Norman; Stanford University, Geophysics } \\
\text { Tsujimori, Tatsuki; Tohoku University, Center for Northeast Asian Studies, }\end{array}$ \\
\hline Keyword: & $\begin{array}{l}\text { Hadean-Archean-Proterozoic plate tectonics, top-down convection, bottom- } \\
\text { up convection, supercratonal assemblies, crust-mantle evolution }\end{array}$ \\
\hline
\end{tabular}

\section{SCHOLARONE"}

Manuscripts 


\title{
Plate-tectonic evolution of the Earth: bottom-up and top-down mantle circulation
}

\author{
W. G. Ernst ${ }^{1}$, Norman H. Sleep ${ }^{1}$, and Tatsuki Tsujimori ${ }^{2}$ \\ ${ }^{1}$ School of Earth Sciences; Stanford University; Stanford, CA 94305-2115; U. S. A. \\ ${ }^{2}$ Center for Northeast Asian Studies, Tohoku University, Sendai, Miyagi 980-8576, Japan
}

\begin{abstract}
Intense devolatilization and chemical-density differentiation attended accretion of planetesimals on the primordial Earth. These processes gradually abated after cooling and solidification of an early magma ocean. By 4.3 or $4.2 \mathrm{Ga}$, water oceans were present, so surface temperatures had fallen far below lowpressure solidi of dry peridotite, basalt, and granite, $\sim 1300, \sim 1120$, and $\sim 950^{\circ} \mathrm{C}$, respectively. At less than half their T solidi, rocky materials existed as thin lithospheric slabs in the near-surface Hadean Earth. Stagnant-lid convection may have occurred initially but was at least episodically overwhelmed by subduction because effective, massive heat transfer necessitated vigorous mantle overturn in the early, hot planet. Bottom-up mantle convection, including voluminous plume ascent, efficiently rid the Earth of deepseated heat. It declined over time as cooling and top-down lithospheric sinking increased. Thickening and both lateral extensional + contractional deformation typified the post-Hadean lithosphere. Stages of geologic evolution included: (a) 4.5-4.4 Ga, magma ocean overturn involved ephemeral, surficial rocky platelets; (b) 4.4-2.7 Ga, formation of oceanic and small continental plates were obliterated by return mantle flow prior to $\sim 4.0 \mathrm{Ga}$; continental material gradually accumulated as largely sub-sea, sialic crust-capped lithospheric collages; (c) 2.7-1.0 Ga, progressive suturing of old shields + younger orogenic belts led to cratonal plates typified by emerging continental freeboard, increasing sedimentary differentiation, and episodic glaciation during transpolar drift; onset of temporally limited stagnant-lid mantle convection occurred beneath enlarging supercontinents; (d) 1.0 Ga-present, laminar-flowing asthenospheric cells are now capped by giant, stately moving plates. Near-restriction of komatiitic lavas to the Archean, and appearance of multicycle sediments, ophiolite complexes \pm alkaline igneous rocks, and high-pressure/ultrahigh-pressure (HP/UHP) metamorphic belts in progressively younger Proterozoic and Phanerozoic orogens reflect increasing negative buoyancy of cool oceanic lithosphere, but decreasing subductability of enlarging, more buoyant continental plates. Attending supercontinental assembly, density instabilities of thickening oceanic plates began to control overturn of suboceanic mantle as cold, top-down convection. Over time, the scales and dynamics of hot asthenospheric upwelling versus lithospheric foundering + mantle return flow (bottomup plume-driven ascent versus top-down plate subduction) evolved gradually, reflecting planetary cooling. These evolving plate-tectonic processes have accompanied the Earth's thermal history since $\sim 4.4$ Ga.
\end{abstract}

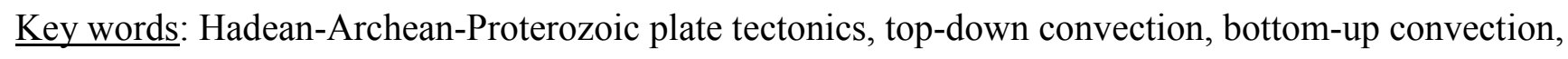
supercratonal assemblies, crust-mantle evolution, stagnant-lids. 


\section{INTRODUCTION}

Our goal is to sketch the thermotectonic history of the Earth's lithosphere-asthenosphere system in order to provide clearer constraints on the onset and evolution of plate-tectonic processes, the apparently incremental growth of sialic crust, and the Proterozoic rise of supercontinents (e.g., see Nutman et al. 2015). We combine geologic, petrologic, geochronologic, geochemical and structural information in a planetary framework in order to minimize some of the uncertainties involved in extrapolating so far back in time. Our resultant plate-tectonic scenario is an approximation, but may inspire other researchers to provide an improved synthesis.

Lithosphere-asthenosphere coupling and mantle circulation reflect a cause-and-effect relationship. But how and when did plate tectonic processes commence, very early in Earth history (Kröner 1981; Ernst 1983; Sleep 1992, 2005; Komiya et al. 1999; Parman et al. 2001; Polat et al. 2002; Smithies et al. 2003, 2005a; Condie 2005; Cawood et al. 2006; Dilek and Polat 2008; Nutman et al. 2009; Sleep et al. 2014; Turner et al. 2014) or much later (Davies 1992; Hamilton 1998, 2003, 2007; Stern 2005, 2007, 2008; Dewey 2007; Brown 2008; Shirey and Richardson 2011; Shirey et al. 2013)? In a sense, this is just a terminological problem, for the early, hot mantle must have circulated beneath a mobile outer rind since solidification of the postulated magma ocean. Once thermally driven mantle flow began, how did lithosphere-asthenosphere interactions change over time? Chemical evolution of the Earth (Hazen et al. 2008) testifies to the gradual maturing and increasing mineralogic complexity of the terrestrial lithospheric-asthenospheric system in response to the thermally driven P-T-compositional history of the planet.

\section{FORMATION OF THE EARTH}

Numerical models suggest that the solar system condensed from a dense cloud of interstellar gas that spun up to form a rotating disc (Safronov 1972; Cameron 1978; Taylor 1992) around a new T Tauri protoSun (Hutchison et al. 2001). Sweep-up of planetesimals in the solar disc gave rise to Sun-orbiting planetary bodies (Shoemaker 1984). Early condensates may have arrived cold, but impact heating of the growing mass and gravitational acceleration would have produced an increasingly hotter accreting Earth (Wetherill 1976; Kaula 1979; Zahnle et al. 2007). This initial planetary phase was completed by 4.6 Ga (Patterson 1956; Papanastassiou and Wasserburg 1971; Amelin et al. 2002). Largest of the four terrestrial planets, the Earth is the only body in the solar system that currently exhibits plate-tectonic processes (Stevenson 2003). The other inner planets are too small to have retained sufficient internal heat since planetesimal accretion to drive an overturning lithosphere-asthenosphere system (Head and Solomon 1981); Mercury, Venus, and Mars have high surface-to-volume ratios, so possess strong lithospheres (Hansen 2007). For somewhat larger bodies, Valencia et al. (2007) calculated that terrestrial-type exoplanets ranging from 1 to 10 Earth masses could have retained enough heat to require advection and plate-tectonic behavior. 
Decay of long-lived radioactive isotopes (e.g., $\left.\mathrm{U}, \mathrm{Th},{ }^{40} \mathrm{~K}\right)$ and especially short-lived isotopes (e.g., ${ }^{26} \mathrm{Al}$ ) further heated the young Earth (Lee 1970). Molten, negatively buoyant Fe-Ni melts sank toward the planetary center and accumulated as a metallic liquid core, overlain by a largely solid $\mathrm{Mg}+\mathrm{Si}$-rich, refractory mantle (Elsasser 1963; Stevenson 1983; Kleine et al. 2004). Due to conversion of potential and kinetic energy to heat, infall of the core raised planetary temperatures substantially, causing more complete separation of liquid Fe-Ni from the solid, Mg-rich silicate mantle (Birch 1965; Flaser and Birch 1973; Golabek et al. 2008). The apparent very early impact of a Mars-sized body supplied additional heat and flung chiefly mantle material into a satellitic Earth orbit (Wetherill, 1988 1990; Cameron and Benz 1991; Halliday 2004; Carlson et al. 2014). Judging by petrochemical-isotopic data for the Moon and meteorites, a near surface, hundreds-of-km-thick terrestrial magma ocean (Stolper et al. 1981; Herzberg 1987; Abe 1997; Davies 1999; Elkins-Tanton 2008; Sleep et al. 2014) formed after this 4.5 Ga impact (Boyet and Carlson 2005; Kleine et al. 2005; McSween 2015; Bottke et al. 2015), then cooled and solidified.

Sleep et al. (2014) showed that on the early Earth, insufficient internal thermal heat sources (i.e., energy generated by planetesimal impact, infall of the core, and radioactivity + energy released by tidal coupling) were available to keep a magma ocean molten more than 20 Myr after the Moon-forming collision. Thus, the terrestrial surface likely was solid by 4.5-4.4 Ga (see also Harrison et al. 2008). A long-lived thermal state where heat flow was an order of magnitude greater than the present value could not be maintained. Radioactive heat available during 4.4 to 4.0 Ga was slightly more than current mantle heat flow. Consequently, Late Hadean and even Early Archean mantle circulation and plate tectonic processes could have been relatively sluggish (Korenaga 2006; Foley et al. 2014).

The low-pressure, anhydrous melting temperature of granite, $\sim 950{ }^{\circ} \mathrm{C}$, takes place $150-200{ }^{\circ} \mathrm{C}$ below the solidi of dry mantle peridotite, $\sim 1300{ }^{\circ} \mathrm{C}$ and basalt, $\sim 1120{ }^{\circ} \mathrm{C}$, and the presence of $\mathrm{H}_{2} \mathrm{O} \pm \mathrm{CO}_{2}$ would have lowered these $\mathrm{T}$ values further (see Fig. 1). Thus by $4.4 \mathrm{Ga}$, a thin refractory, rocky skin must have formed, accounting for the presence of detrital grains of 4.3-4.2 Ga igneous zircons that crystallized from western Australian, now-eroded granitoids (Compston and Pigeon 1986; Mojzsis et al. 2001; Wilde et al. 2001; Watson and Harrison 2005; Harrison 2009; Hopkins et al. 2008, 2010). Remanent magnetism measured in single zircon crystals also supports the presence of shallow-level sialic crust by $4.2 \mathrm{Ga}$ (Tarduno et al. 2015). To form such a protocrust, solid oceanic crust and uppermost mantle must have been extant in the near-surface environment at P-T conditions well below their fusion temperatures. However, such Hadean crust apparently was totally recycled by viscous drag into the overturning mantle (Amelin et al. 1999; Boyet and Carlson 2005; Scherer et al. 2007). The 4.03 Ga granitic orthogneisses of NW Canada appear to be the oldest well-documented, surviving terrestrial rocks (Bowring and Williams 1999; Mojzsis et al. 2014). Based on Nd-Sm bulk-rock analyses, O'Neil et al. (2008, 2011) reported the existence of yet older $\sim 4.28$ Ga rocks in the Nuvvuagittuq greenstone belt, NE Canada, but Cates et al. (2013) indicated a 
possible maximum age of $\sim 3.78 \mathrm{Ga}$ for these supercrustals. In any case, water-laid metasedimentary rocks in western Greenland requires that tracts of the Earth's surface had cooled below the boiling point of $\mathrm{H}_{2} \mathrm{O}$ by 3.8 Ga at the very latest (Moorbath et al. 1972; Moorbath 1984; Nutman et al. 1997; Komiya et al. 2009, 2015) but possibly up to at least 300 Myr earlier (Wilde et al. 2001; Mojzsis et al. 2001, Valley et al. 2002; Harrison 2009; Sleep et al. 2014). Apparently, segments of solid crust and mantle were present in the early Earth (Davies 2006, 2007; Hynes 2008). Reflecting the ubiquity of mafic pillow lavas and complete lack of mature, multicycle sedimentary rocks (Ronov and Migdisov 1971; Condie 1982, 1998), a globeencircling water ocean bathed the planetary surface several hundred million years before stabilization of the surviving Archean rock record (Mojzsis et al. 2001; Sleep et al. 2001; Harrison et al. 2005; Trail et al. 2007).

Jackson et al. (2008) showed that seismogenic activity and plate-like behavior typifies rock units at P-T conditions less than about half their T solidi. Thus, by $4.4 \mathrm{Ga}$ the Earth's surface must have been underlain by small lithospheric platelets. The early Earth may have been attended by periods of stagnant-lid mantle circulation (O’Neill and Debaille 2014; Griffin et al. 2014), punctuated by at least episodic overturn as seems required by the terrestrial heat budget. Conduction is much less efficient at transferring thermal energy than is convection-advection (Sleep 2000). Therefore, primitive plate-tectonic processes evidently began during Hadean time (i.e., 4.4-4.0 Ga: Hopkins et al. 2008; Foley et al. 2014; Turner et al. 2014). Thickening of lithospheric platelets probably occurred gradually, reflecting thermal relaxation of the planet. In several ancient cratons, diamonds as old as $\sim 3.5 \mathrm{Ga}$ have been dated from kimberlite pipes (Richardson et al. 1984; Jacob 2004; Shirey et al. 2004, 2013; Westerlund et al. 2006; Shirey and Richardson 2011), so by the Early Archean, some segments of the Earth must have been typified by thick lithosphere subjected to differential plate motions (see Fig. 1). Locally thick Hadean lithosphere was postulated to account for microdiamond "inclusions" in detrital zircons as old as 4.3-4.2 Ga from western Australia (Menneken et al. 2007), but these microdiamonds are now viewed as introduced during sample polishing (Dobrzhinetskaya et al. 2014).

The planets and satellites of the inner solar system are pockmarked by ancient impacts; some exhibit the effects of post-accretion tectonism, weathering, and erosion. Development of erosional and depositional features is a function of planetary mass (Head and Solomon 1981; Valencia et al. 2007). Large bodies such as the Earth, Venus, and Mars have undergone different degrees of resurfacing, whereas surficial reworking is nearly lacking on Mercury and the Moon. Small bodies, and those especially close to the Sun have insufficient gravitational attraction to retain their original complement of volatiles, which consequently largely escaped into space; those distant from the Sun are too cold to allow formation of a water ocean. The Earth, however, possesses an appropriate mass and orbital location for effective retention of volatiles, allowing sequestration of $\mathrm{H}_{2} \mathrm{O}$ in the atmosphere, the surface ocean, and in the solid body. In contrast to the 
$\mathrm{CO}_{2}$-rich atmosphere of Venus, persistence of the terrestrial oceans allowed $\mathrm{CO}_{2}$ in aqueous solution to be combined with $\mathrm{Ca} \pm \mathrm{Mg}$ and precipitated chiefly as carbonate-rich marine strata, and as alteration products of oceanic lithosphere sinking back into the mantle.

Sleep et al. (2014) envisioned two likely end-member conditions for the Earth's earliest atmosphere. (1) Directly after the Mars-sized impact, total vaporization of volatile species would have produced a massive C-O-H greenhouse characterized by $\sim 10 \mathrm{MPa}$ of $\mathrm{CO}_{2}$. Initial surface temperatures would have exceeded $200{ }^{\circ} \mathrm{C}$, but on cooling, most of the $\mathrm{H}_{2} \mathrm{O}$ in the atmosphere precipitated, forming the globeencircling oceans. The remaining $\mathrm{CO}_{2}$-rich atmosphere, strongly out of chemical equilibrium with the lithosphere, progressively reacted to form calcareous sedimentary rocks and carbonate-altered oceanic basalt. (2) Thus, on subduction, the $\mathrm{CO}_{2}$ pressure would have declined toward a pressure of $0.1 \mathrm{MPa}$ (1 bar). Once most of the $\mathrm{CO}_{2}$ was removed from the atmosphere, clement-to-cold surface temperatures would have typified the terrestrial surface. This is a consequence of the fact that the Sun was so weak during the Hadean that 1 bar $\mathrm{CO}_{2}$ atmosphere $+\mathrm{N}_{2}$ would have provided an environment hospitable for life (Sleep et al. 2001; Rosing et al. 2010). Geologic evidence indicates that banded iron formations and black shales are among the oldest sediments, and may have supported life through Fe- and S-based photosynthesis (Mojzsis et al. 1996; Sleep and Bird 2007). By 3.8 Ga, oceanic crust, primitive sialic crust, and thin lithospheric plates surmounting a convecting mantle would have provided plate-tectonic environments hospitable for life.

As shown in Figure 1, polar molecules like $\mathrm{H}_{2} \mathrm{O}$ are very soluble in silicate melts, strongly lowering fusion temperatures. This solubility of volatiles enhances the planetary capacity for solid-liquid-vapor fractionation-differentiation, and by lowering solidus temperatures, decreases the depth of the lithosphereasthenosphere transition relative to anhydrous P-T conditions. Partial melting generates high-T density instabilities in the deep Earth. Upwelling mantle and diapiric decompression melts thus serve as vehicles efficiently promoting surfaceward transfer of buried heat. Such bottom-up advective transport is manifest especially by deep-seated mantle overturn and by rising plumes (e.g., Yuen, et al. eds. 2007; French and Romanowicz 2015). Coupled with return flow, this type of mantle circulation represented an important mechanism for the differential transport and tectonic reworking of the low-density rocky veneer that consolidated early in terrestrial history. With cooling, a thicker, buoyant continental lithosphere gradually became stabilized in the near-surface environment. Concomitantly over time, growth of thicker, cooler, denser basaltic crust-capped plates resulted in enhanced gravitational instability of the oceanic lithosphere, causing top-down convective overturn in the suboceanic upper mantle. Thus, both bottom-up and top-down mantle circulation characterize the evolution of the planet, driven by thermal/chemical gravitational overturn; plume ascent was more important attending the high-T early Earth, whereas by degrees, the plate sinking came to dominate later, cooler stages of mantle flow.

TERRESTRIAL HEAT CONTENT AND MANTLE CIRCULATION https://mc06.manuscriptcentral.com/cjes-pubs 
We distinguish between heat sources within the mantle, its internal temperature, changing rates of global tectonics, and effects of tectonic processes on the rock record preserved almost exclusively within the continental crust. It is generally regarded that the Earth's surface and interior were hottest shortly after the hypothesized Mars-sized collision, and that temperatures have progressively declined ever since (e.g., Davies 1980, 2009). Wanke et al. (1984) estimated that the global heat from accretion and from $\mathrm{Fe}+\mathrm{Ni}$ core formation was far greater than the heat subsequently released by radioactive decay of K, Th, and $U$. More recent analyses posit accretion of the Earth from large bodies with already differentiated cores, ending in the Moon-forming impact, but do not change this basic conclusion. Most of the gravitational heat from accretion and core formation had escaped by $20 \mathrm{Myr}$ after the Moon-forming impact through circulation of the magma ocean (Sleep et al. 2014). The planetary interior was chiefly solid. Subsequent cooling and radioactive decay over geologic time have contributed comparable amounts of heat.

Regarding the importance of radioactivity, geodynamicists define the Urey number as the ratio of current global radioactive heat production to global heat loss. The latter quantity is well constrained because much of the heat flow reflects the geometrically simple cooling of oceanic crust. The present mantle heat flux is estimated to be $35 \mathrm{TW}$, equivalent to a globally averaged mantle heat flow of $0.070 \mathrm{~W} \mathrm{~m}^{-2}$ (Perry et al. 2009; Mareschal et al. 2012). Studies of geoneutrinos (antineutrinos from U and Th decay) reflect the current radioactive heat production (Krauss et al. 1984; Araki et al. 2005; Dye ed. 2007; Tolich 2012; Bellini et al. 2013). Antineutrinos from ${ }^{40} \mathrm{~K}$ decay within the Earth cannot presently be detected. Geochemists infer the $\mathrm{K} / \mathrm{U}$ ratio and hence the total radioactive heat production through studies of element ratios in mantle-derived rocks (e.g., McDonough and Sun 1995).

Current estimates suggest that the Urey ratio is less than $1 / 3$ with a compiled range of 0.08 to 0.3 (Šrámek et al. 2012, 2013). If these values are globally applicable, the interior of the Earth is now cooling. For reference, cooling supplies all the present mantle heat flow of $0.070 \mathrm{~W} \mathrm{~m}^{-2}$ at a Urey number of zero. Then the whole mantle would need to cool at $225 \mathrm{~K} / \mathrm{Gyr}$ and the entire Earth would need to cool at 180 K/Gyr (i.e., degrees of cooling per billion years; Sleep et al. 2014). A low Urey number implies that mantle radioactivity was not an intense heat source during the Hadean (Korenaga 2006, 2008a, 2008b; Herzberg et al. 2010; Foley et al. 2014). The global mantle heat flow in balance with radioactivity was comparable to or even less than the current mantle heat flow. Accordingly, ancient plate tectonic rates did not have to be significantly greater than present ones. It is even possible that Hadean and Archean rates were sluggish compared to modern rates (Korenaga 2006). If so, the Earth's interior may have gradually heated during the Hadean and Early Archean, and reached a maximum before $\sim 3 \mathrm{Ga}$.

In any case, Hadean and Archean mantle temperatures were higher than modern values (Fig. 1). The effects of such temperatures on the kinematics of tectonics and volcanism needed to be distinguished from the effects on rates. In this regard, Sleep $(2000,2007)$ described three types of planetary heat transfer 
potentially applicable once solid lithosphere formed on the Earth: (i) magma oceans; (ii) plume + plate tectonics; and (iii) stagnant-lid convection. The first, most energetic mode likely typified the Early Hadean stage of terrestrial evolution. The third, least energetic mode now operates on Venus and Mars, but is only locally present on Earth beneath stable, nonsubducting continental plates. Much of the modern, Wilsoncycle $^{1}$ of plate-tectonic heat dissipation reflects convective overturn in the suboceanic lithosphereasthenosphere system. In contrast, sialic craton-capped lithosphere acts as a stagnant insulating lid, leading to the build-up of sublithospheric $\mathrm{T}$ and consequently, episodic continental break-up and dispersal (Gurnis 1988; Lowman and Jarvis 1996; Silver and Behn 2008). During rifting and subduction, some low-density lithosphere is returned to the mantle by viscous drag. However, Lenardic et al. (2003) showed that a high brittle yield strength, combined with chemical-mineralogical buoyancy and a high-viscosity crustal root promotes long-term stabilization of cratonal lithosphere relative to denser oceanic plates (Irifune 1993), whereas the latter are continuously recycled back into the deep Earth. Granitic crust thus has accumulated, especially during early geologic time.

Mantle convection is propelled by both bottom-up and top-down, T-induced density instabilities, i.e., hot, buoyant, plume-driven mantle overturn, and cold, dense, sinking lithospheric slabs, respectively (Davies 1999; Anderson 2001; Maruyama et al. 2007; Crameri et al. 2012). The existence of deep-seated, elevated temperatures and surficial platelets in the Hadean Earth suggest that times of widespread, vigorous overturn and plume ascent from the base of high-temperature mantle realms mainly powered convection (Lambert 1981; Davies 1993; Condie 1994, 2005; Sleep 2007). Rather than achieving a dynamic steady state, high-T regimes and low mantle viscosities in the early Earth might have led to episodes of rapid seafloor spreading, fast-moving plates, and avalanches of platelet descent into the lower mantle, as well as to major intervals of relative quiescence, according to analyses by Moresi and Solomatov (1998), O’Neill et al. (2007), and Sleep et al. (2014). A general sluggishness of Hadean plate motions was also postulated by Korenaga (2006, 2008a, 2008b), Herzberg et al. (2010) and Foley et al. (2014).

By 3.0-2.5 Ga, thermal heterogeneities in the deep mantle evidently had lessened. Due to longer residence times at the surface and thus greater heat losses, progressively cooler, thicker, oceanic lithospheric plates would have become more negatively buoyant, resulting in foundering, driving mantle convection from the planetary surface downward (Anderson 1987; Conrad and Lithgow-Bertelloni 2002; Anderson and Natland 2014). Craton-capped plates are chemically-mineralogically buoyant, hence are preferentially retained at the Earth's surface. Most of today's heat loss occurs in and around oceanic spreading centers

\footnotetext{
${ }^{1}$ The opening and closing of oceanic basins, first emphasized by J. Tuzo Wilson (Wilson 1968). Divergent plate boundaries are marked by low-P, high-T production of new oceanic lithosphere, preserved in the rock record as ophiolite complexes and greenstone belts. Convergent plate boundaries are characterized by landward, high-T calcalkaline arcs and seaward, high-P subduction zones, the latter including Phanerozoic blueschist and eclogite belts - lithologic assemblages disfavored in a hotter Precambrian Earth (Ernst 1972).
} 
whereas, because heat flow decreases approximately with the square root of crustal age, thermal fluxes in older parts of the oceanic crust and in continental assemblies possessing depleted keels are substantially lower. Thus mantle heat flow through the sialic crust represents a minor global contribution (Sclater et al. 1980; Van Kranendonk et al. 2004).

The early Earth supported a higher internal mantle temperature, reflected by the abundance of Archean komatiites, but their near absence from Proterozoic and younger rocks. Depending on their $\mathrm{H}_{2} \mathrm{O}$ contents, low-viscosity ultramafic lavas characteristic of ancient greenstone belts were completely molten at temperatures in the range 1300-1600 ${ }^{\circ} \mathrm{C}$ (Green 1975, 1981; Nisbet et al. 1977; Abbott et al. 1994; Grove and Parman 2004), requiring relatively large degrees of partial melting of an upwelling, fertile mantle. Such komatiitic liquids could only have formed in oceanic and rifted continental regions of elevated heat flow above hot, upwelling mantle. In contrast, thick, coherent crustal sections of high-grade granulitic gray gneiss (TTG) typify Archean cratons (Lambert 1976; Boyd et al. 1985; Polat et al. 1998; Artemieva and Mooney 2001; Sleep 2005; Brown 2008: Kisters et al. 2012; Wang et al. 2013), demonstrating that some regions of the continental lithosphere were subjected to warm but less extreme geothermal gradients.

Hadean mantle circulation apparently was dominated by poorly organized, small asthenospheric cells (Condie 2005; Ernst 2007) and by plume-driven advective heat transfer (Abbott et al. 1994; Tackley 2000), bringing thermal energy to the surface. Mantle return flow may have resulted in the accumulation of deep-seated refractory residua, but no rock record is known for this inferred chaotic period of Earth history. As major T anomalies in deep-seated mantle declined, and near-surface sections cooled below peridotite and basalt solidi, Archean production of mantle plumes and small, rapidly overturning asthenospheric cells would have promoted the continuing transfer of heat from the mantle toward the surface-even if ponded plume material collected at the base of the lithosphere, and was underlain by cooler mantle. Driven chiefly by bottom-up mantle flow, a thin, discontinuous rind of lithosphere must have capped these circulating systems, and platelet tectonics would have begun. Compared with the present-day planet, lowered viscosity in a hotter Archean mantle probably allowed periods of more rapid circulation (O'Neill et al. 2008) and in much smaller scale convection cells typified by lower aspect ratios (Turcotte and Schubert 1982). The horizontal dimensions of these circulating systems evidently were controlled by the high-T, thin lithospheric platelets, and by the rapid ascent of columns of hot, buoyant mantle.

In contrast to the modern configuration dominated by differential motions of large-scale plates and their underlying laminar-flowing convection cells (Anderson 2005), the Early Archean Earth probably was typified by oceanic regions underlain by numerous small, rapidly circulating upper mantle cells, with immature island arcs + continental debris entrained into cooler regions of mantle stagnation or regional downwelling (Baer 1981a, b; Boak and Dymek 1982; Ernst 1983; Richter 1984; Smithies et al. 2007). This scenario may account for the surviving Archean rock record, if the dimensions of asthenospheric convection 
cells mirror the structures and sizes of the preserved continental crustal units and their inferred mantle lithospheric underpinnings. Convergent plate-tectonic features of accretionary complexes, forearc basins and alkaline igneous arcs of the present-day continental crust are recognizable in some Proterozoic orogens (e.g., Windley 1995; Lucas et al. 1996; Korsman et al. 1999; Cook et al. 1999; Condie 2005). Apparently the disaggregated, small-scale architectures of Archean granite-greenstone belts and spatially associated TTG terranes (Goodwin 1981a, b; Percival et al. 1994) evolved by degrees into the long, pairedmetamorphic + volcanic-plutonic belts typical of the Phanerozoic Era (Miyashiro 1961, 1972). Of course, over the broad sweep of geologic time, progressive accumulation of rifting, drifting, and suturing episodes undoubtedly has fragmented the rock record of ancient crustal amalgams; the surviving orogens are likely more dislocated and dispersed than were the original belts.

\section{SEPARATION AND GROWTH OF THE CONTINENTAL CRUST}

Formed by decompression partial melting of rising asthenospheric columns, modern oceanic crust and its depleted mantle underpinnings cool, recrystallize, are partially hydrated-carbonated, and return to the deep upper mantle. Probably, mafic-ultramafic lithosphere also was carried back into the Archean mantle by return flow necessary to accommodate new oceanic plates continuously generated by active mantle overturn and ascending plumes. The fate of descending oceanic plates is yet debated, but in the Phanerozoic, their devolatilization and partial melting and/or that of the overlying, refertilized, slightly more oxidized mantle wedge \pm mafic igneous rocks underplated beneath sections of the sialic crust have produced the calcalkaline magmas that typify mature island arcs and active continental margins (Green and Ringwood 1967; Martin 1986; Rudnick 1995; Rapp et al. 1995; Tatsumi 2000; Stern 2002; Brounce et al. 2015). Intermediate and silicic igneous rocks are less refractory and more buoyant than the mantle, so are selectively retained near the Earth's surface. Along with off-loaded accretionary prisms, underplated subducted trench deposits, stranded microcontinental terranes, and tectonic slices of oceanic crust, calcalkaline plutonic + volcanic rocks have accumulated over time and make up the chemically-mineralogically buoyant continental crust. Many crustal rocks consist of recycled material, but igneous arcs have provided virtually all of the juvenile additions to the granitic crust; other secondary rocks, including metamorphic and sedimentary lithologies represent reworking of the calcalkaline suite (Ernst 1999; Tatsumi 2005).

Almost all Early Archean crustal rocks were returned to the mantle, likely due to viscous coupling attending rapid asthenospheric circulation (Condie 1980, 2005; Hargraves 1981; Lenardic et al. 2003; Rogers and Santosh 2004). Bulk-rock isotopic data suggest that thorough reincorporation of sialic materials into the mantle continued until $\sim 3.8 \mathrm{Ga}$, that the average age of continental crust separated from the mantle is $\sim 2.3 \pm 0.5 \mathrm{Ga}$, and that much of this material (70\% or more) was generated by Late Archean or Early Proterozoic time (Veizer 1976; Jacobson and Wasserburg 1981; DePaolo 1981; Nelson and DePaolo 1985; Taylor and McLennan 1985; Turcotte and Kellogg 1986; DePaolo et al. 1991; Condie 1998; Hawkesworth 
et al. 2013). Calcalkaline igneous arcs also were produced by Hadean subduction, but long-term preservation of continental crust did not begin until the Early Archean (Moorbath et al. 1972; Komiya et al. 2015). The existence of igneous zircons as old as 4.3-4.2 Ga (Compston and Pigeon 1986; Wilde et al. 2001; Harrison 2009; Hopkins et al. 2008, 2010) in mid-Archean sedimentary rocks reflects at least shortterm near-surface retention of some ancient arc material. By $\sim 3.8 \mathrm{Ga}$ however, the rate of return of juvenile sialic crust to the mantle appears to have fallen below its rate of production. Thus, gradually increasing amounts accumulated as quartzofeldspathic crust and were preserved due to vigorous but decelerating asthenospheric convection, and possibly due to a slight increase in the oxidation state of the uppermost mantle (Catling et al. 2007; Pope et al. 2012). This process removed LIL and incompatible elements from the residual mantle and, as thermal input to the convective system declined, the generation of mafic + felsic crust from progressively more depleted mantle declined toward present low and very low generation rates, respectively. Scholl and von Huene $(2007,2009)$ calculated that the rates of production of new continental crust versus its subduction-induced erosion and return to the mantle are nearly equal today, and may have been so since the Late Archean (see also Armstrong 1968, 1981; von Huene and Scholl 1991; for proposed later stage high crustal growth rates, see Rino et al. 2008). This recycling probably has contributed to geochemical heterogeneities, including slight oxidation, of the upper mantle.

Based largely on isotopic data, the rate of episodic or continuous additions of mass to the continental crust reached a peak in the Late Archean ( 2.7 Ga), and apparently has decreased ever since (O’Nions et al. 1980; Lambert 1980; Jacobsen and Wasserburg 1981; Nelson and DePaolo 1984; Reymer and Schubert 1986; McCulloch and Bennett 1994; O’Neill et al. 2007; Condie 2007; Voice et al. 2011; Valley 2015). Reflecting progressive depletion of crustal components in the convecting mantle source realm over the past $\sim 4$ Gyr, we infer that the rate of formation of juvenile crust has gradually diminished over time, and is now about equal to its rate of return to the mantle. Figure 2 schematically shows progressive net accumulation of granitic crust, based on contrasting assumptions: (a) a smoothly varying function of a gradual thermal relaxation of the planet (Scholl and von Huene 2007, 2009); or (b) a consequence of punctuated rapid mantle overturn and/or continental accretion (Cawood et al. 2013). If the aggregation-suturing of supercontinental assemblies and their subsequent fragmentation-dispersal strongly affect rates of subduction and sea-floor spreading (Moresi and Solomatov 1998; O’Neill et al. 2007; Silver and Behn 2008; Condie et al. 2015), growth and preservation versus destruction of the crust likely was a complex function of time.

\section{THE EARTH'S ROCK RECORD AND PLATE-TECTONIC IMPLICATIONS}

\section{General Petrologic Considerations}

Continents and ocean basins are first-order, near-surface features of the planet, reflecting outward transport of buried heat. Contrasting-density-propelled mantle overturn and differential plate motions generate this ongoing energy transfer. Thermal, gravitational, and petrochemical differentiations need to be 
integrated with the ancient-to-modern terrestrial rock record in order to clarify the changing styles of planetary evolution. An increasingly fragmentary preservation of older rock assemblages is retained only in the continental crust, with nothing more ancient than $\sim 4.0 \mathrm{Ga}$. Contrasts in lithologies reflect markedly different Archean versus Phanerozoic P-T trajectories in both crust and upper mantle, as evident from the metamorphic facies diagram of Figure 3. Most mid-Proterozoic and older continental orogens formed under prograde geothermal gradients of $30^{\circ} \mathrm{C} / \mathrm{km}$ or greater, whereas younger belts recrystallized under a broader realm of P-T trajectories ranging from $\sim 30^{\circ} \mathrm{C} / \mathrm{km}$ to $\sim 5^{\circ} \mathrm{C} / \mathrm{km}$.

The preserved Archean crust is typified by pillowed (i.e., sub-sea) greenstone belts invaded by granitic plutons, komatiitic basalts, and gray tonalitic gneiss terranes, but it lacks mafic alkaline igneous rocks, complete ophiolite sections, mature, multicycle clastic sediments, high-P blueschist + low-T eclogite belts, and UHP continental metamorphic complexes (Ernst 1972, 2007; Maruyama et al. 1996; Rogers and Santosh 2004; Bailey and Woolley 2005; Stern 2005, 2007, 2008). Some of the distinctive lithologies readily assigned to Wilson-cycle plate-tectonic processes, such as blueschists, stratigraphically intact ophiolite suites (Peltonen and Kontinen 2004) and chemically-mineralogically evolved, multicycle platform sedimentary strata (Fig. 4) do not appear unequivocally in the rock record until the end of Archean or later time. Archean ophiolites reported by Furnes et al. (2007), and by Dilek and Polat (2008) remain controversial. Rare lithostratigraphic structures of Phanerozoic-style accretionary prisms are recognized in some ancient greenstone belts (e.g., Ohta et al. 1996; Komiya et al. 1999). However, fossil geotherms suggested by Precambrian metamorphic facies series substantially exceed those of Phanerozoic HP/UHP belts (e.g., Komiya et al. 2002; Diener et al. 2006). Middle Archean blueschist-facies metamorphism was proposed for a garnet amphibolite from the Barberton terrane of South Africa (Moyen et al. 2006), whereas the rock actually contains hornblende — not glaucophane. Nevertheless, relatively high-P conditions also were suggested for a South African greenschist (Ganne et al. 2012).

Certain eclogites formed at relatively elevated temperatures, such as characterize high-grade gneiss terranes and xenoliths in kimberlite diatremes (Coleman et al. 1965). These high-T eclogites occur as lenses + pods in their host rocks; a few are as old as Proterozoic or possibly even latest Archean. Figure 5 shows general petrologic-geothermal relationships over time of the continental crust (see also Valley 2015). The oldest crustal eclogite occurrences are latest Early Proterozoic, associated with high-P granulites in the Usagaran-Ubendian mobile belts of Tanzania (Sklyarov et al. 1998; Möller et al. 1995; Boniface et al. 2012). Archean eclogite was reported from the Kola Peninsula, Russia (Volodichev et al. 2004; Mints et al. 2010), but U-Pb zircon geochronology identified Early Proterozoic metamorphic rims around Archean magmatic zircon cores (Skublov et al. 2011). Eclogites, particularly those formed in a transitional eclogitegranulite facies P-T range, thus are not necessarily indicators of subduction-zone metamorphism. Evidently such high-T metabasaltic eclogites can form in deep continental crustal roots ( $>60 \mathrm{~km}$; e.g., De Paoli et al. 
2009). Significantly, no reports of Early Proterozoic jadeite + quartz assemblages or lawsonite exist that would attest to modern-style P-T subduction-zone environments (Ernst 1972; Tsujimori and Ernst 2014).

Unambiguous indicators of plate underflow-blueschist + low-T eclogite belts and HP/UHP cratonal subduction complexes (Figs. 3 and 5) — date from about 0.75 and 0.53 Ga respectively (Ernst 1983; Scott et al. 1992; Maruyama et al. 1996; Kusky et al. 2001; Condie 2005; Polat et al. 2005, 2007, 2008; Brown 2006, 2008; Tsujimori and Ernst 2014). Eclogitic micro-inclusions in diamonds as ancient as 3.0 Ga were reported by Shirey and Richardson (2011), and have been interpreted by these authors as marking the onset of the Wilson cycle of plate tectonics. These and other Proterozoic and possible Late Archean eclogitic occurrences could well have been generated in subduction zones. However, although more ancient kimberlitic diamonds are known (i.e., 3.5 G; Westerlund et al. 2006), eclogites older than 3.0 Ga have never been clearly documented. Either such diagnostic lithologies were obliterated by later tectonic and/or erosional events, or eclogites did not form during the petrotectonic development of Archean TTG-granitegreenstone belts, probably due to substantially higher geothermal gradients.

Did plate tectonics operate on the early Earth? Advective heat transfer attended terrestrial evolution since infall of the Fe-Ni liquid core, formation of the Moon and solidification of a magma ocean at 4.5-4.4 Ga, but rocks have not survived from Hadean time. Nevertheless, a peripheral solid rind and small, thin, platelets intruded by granitoids must have bounded the rocky surface by 4.3-4.2 Ga, judging from igneous zircons with such $\mathrm{U}-\mathrm{Pb}$ ages. Lowermost Archean metasedimentary strata require that the hydrosphere was extant no later than $3.8 \mathrm{Ga}$, but a liquid $\mathrm{H}_{2} \mathrm{O}$ ocean may have been present much earlier (Wilde et al. 2001; Mojzsis et al. 2001; Watson and Harrison 2005; Zahnle et al. 2007; Sleep et al. 2014). Thus, lithosphere at less than half its fusion T (Jackson et al. 2008) was clearly present prior to ages of the oldest surviving rocks. The relatively cool modern Earth exhibits asthenospheric overturn, in the process bringing deepseated heat to the surface, and it must have transported thermal energy surfaceward yet more vigorously during its higher temperature, higher geothermal gradient geologic past, dominated by bottom-up, hot, buoyant (Smithies, et al. 2005b) and to a lesser extent by top-down, cold, negatively buoyant (Moyen et al. 2006) gravitational instabilities. Lithospheric plates thus were present at the Earth's surface since solidification of a magma ocean at $4.5-4.4 \mathrm{Ga}$. However, the scales and aspect ratios of the plates, as well as the rates of mantle circulation probably have changed dramatically over geologic time.

\section{Hadean-Archean Platelet Stage}

On the very young Earth, most of the $\mathrm{C}-\mathrm{O}-\mathrm{H}$ volatiles not sequestered within the planetary interior formed a dense, highly reducing atmosphere; initially, the surface was too hot to form a condensed hydrosphere (Sleep et al. 2014). Rapidly circulating, poorly organized mantle cells would have driven surficial segments of a semisolid lithospheric rind against and beneath one another. Reflecting elevated mantle temperatures and thus thinness of slabs typified by small lithosphere-asthenosphere density 
inversions, platelets probably would not have been deeply subducted before heat from the hotter, rapidly overturning mantle eliminated their coherence as discrete platelets. This dynamic thermal regime accounts for the lack of high-P blueschist and low-T eclogite belts in all but the youngest Proterozoic terranes. In Phanerozoic Wilson-cycle subduction zones, thick lithospheric plates carry relatively cool rocks to great depths, allowing the formation of UHP sialic complexes. In marked contrast, Archean underflow carried down small, warm slabs, which were rapidly heated, to mantle temperatures, generating low-P/high-T terranes. Modern alkalic mafic igneous rocks such as ocean-island basalts form through very small degrees of partial fusion of the deep upper mantle, but are virtually lacking in Archean crust because the Earth's ancient geothermal gradient was too high. Instead, due to elevated T, larger degrees of partial melting at relatively shallow mantle depths produced substantial volumes of refractory komatiitic lava. Some ancient sections of oceanic crust were relatively thick — surmounting thin lithospheric mantle - due to extensive partial melting of virtually undepleted mantle (Sleep and Windley 1982).

The occurrence of ductile microplates also may account for the small scale of the surviving Archean granite-greenstone belts, assuming that the mafic rocks formed as oceanic crust, then were sutured against primitive sialic island arcs (e.g., Percival et al. 1994; Mueller et al. 2002; Wyman et al. 2002; Garde 2007; Szilas et al. 2012; Komiya et al. 2015). These oceanic arcs include abundant pillow lavas, so were covered by shallow seas, reflecting early Earth condensation of $\mathrm{H}_{2} \mathrm{O}$ from the cooling atmosphere. With the Archean rise of cyanobacteria, anaerobic photosynthesis gradually generated a more oxidized hydrosphere and atmosphere \pm lithosphere (e.g., Nesbit and Sleep 2001; Oyarzun et al. 2008). The decomposition of methane and escape of $\mathrm{H}_{2}$ into space may also have contributed to progressive oxidation (Catling et al. 2007; Pope et al. 2012). Alternatively, some greenstone complexes might have been generated at shallow, slightly more oxidized depths by fractional crystallization of basaltic magma (i.e., Bowen 1928; Sisson et al. 2004), through partial fusion of high-T eclogite and/or garnet amphibolite (Green and Ringwood 1967; Holloway and Burnham 1972; Boettcher 1973; Pertermann and Hirschmann 2003; Dufek and Bergantz 2005; Hamilton 2007; Nair and Chacko 2008), or by incipient melting of hydrous, fertile upper mantle peridotite (Kushiro et al. 1968; Mysen and Boettcher 1975; Arculus 1981; Ulmer 2001). The sweeping together, decapitation, and suturing of near-surface portions of oceanic crust \pm oceanic plateaus against primitive island arcs could have produced the ubiquitous Archean granite-greenstone belts. The size of these amalgams probably mirrors the small lateral dimensions of the convecting Archean asthenosphere (Smithies, et al. 2007). By Early Proterozoic time, sustained planetary cooling resulted in lower geothermal gradients, the generation of thinner sections of oceanic crust, and a deepening of the brittle-ductile transition; thus, complete basalt-gabbro-cumulate peridotite sections of oceanic crust began to behave as integral units, and more complete ophiolite complexes were sheared off and jammed into the accreting 
granitic continental crust during plate underflow, as well as by emplacement through back-arc and intra-arc (i.e., supra-subduction zone) rifting.

\section{Proterozoic Supercontinental Stage}

Combined with igneous differentiation-segregation and anatexis, oceanic island arcs, TTG terranes, and sialic volcanic-plutonic masses that formed chiefly during mantle overturn apparently were sutured and accumulated as buoyant continental cratons, gradually gaining freeboard toward the end of Archean time (Williams et al. 1991; Aspler, and Chiarenzelli 1998; Bleeker 2002, 2003). Enlarging supercontinental entities self-assembled by subduction-induced continental collision, as indicated by production of relatively high-pressure rock types (e.g., Mosher et al. 2008; Brown 2008). This period was also typified by the gradual transition from thin, hot Archean platelets, carried about by many small, rapidly convecting mantle cells and plumes, to relatively thicker, laterally extensive, cooler lithospheric plates. Differential motions of these larger plates probably were a function of mantle flow on a grander scale, as well as due to widespread foundering of the oceanic lithosphere (Ernst 1983).

Archean time apparently was typified by dispersed, mostly sub-sea accumulations of sialic arcs, as is also suggested by the ubiquity of submarine pillows in the preserved greenstone belts. In contrast, emergent landmasses of broad areal extent became common during the Early Proterozoic (Schubert and Reymer 1985; Condie 2007), so erosion and sedimentation began to yield multicycle strata of chemically mature, isotopically contrasting sedimentary facies (Fig. 4). Siliciclastic sediments form through repeated cycles of weathering, erosion and deposition. Continental platforms, and shallow seas provide appropriate geologic environments necessary for the genesis of such rock types. Moreover, by Early Proterozoic time, continental climates combined with high-latitude drift produced episodes of icehouse conditions and glacial deposits. These various relationships reflect the progressive accumulation of sialic material over time, and the occasional construction (and later dispersal) of Proterozoic and younger supercontinental assemblies.

Evolution of the crust-mantle system was manifested in the bulk-rock composition of igneous rocks as well (e.g., Valley et al. 2005). Biologically generated increasing $\mathrm{O}_{2}$ content of the atmosphere resulted in more intense chemical weathering and in further differentiation of superjacent rocks (Holland 1984, 1994, 2002; Kasting 2001; Melezhik et al. 2005; Kump and Barley 2007). Re-injection of subduction-zone volatiles back into the mantle caused aqueous fluid-mediated metasomatism and oxidation of parts of the uppermost mantle. Transpolar drift of supercontinental plates led to glaciation and to yet more strongly contrasting bulk compositions of sedimentary strata.

A result of the episodic formation of supercontinents (Condie 2007; Condie et al. 2015) was that enlarging, sial-capped lithospheric plates not only became chemically-mineralogically more buoyant, but also began to serve as regional thermal insulators, trapping heat flow from the deep Earth. The appearance of supercontinental plates thus promoted a spatially, temporally restricted type of stagnant-lid behavior 
(Sleep 2007). After a sufficient post-amalgamation interval, heat build-up of the subcontinental mantle led to vigorous intraplate convection, spreading, continental rifting, and a renewed cycle of drift. Overturn of the oceanic lithosphere-asthenosphere system is the most efficient method of transferring planetary heat surfaceward (Gurnis 1988; Lowman and Jarvis 1996; Sleep 2007), so it is likely that episodic continental collisions and supercontinental assembly might cause a temporary deceleration in plate-tectonic processes in the oceanic and circum-oceanic realms, rather than in complete cessation of differential plate motion, as speculated by Silver and Behn (2008). Judging from the thermally induced competition between bottom-up and top-down mantle overturn, mantle circulation may well have varied in intensity (O’Neill et al. 2007), but is unlikely to have stopped for a lengthy geologic time period.

\section{Phanerozoic Wilson-cycle Stage}

Ophiolite lithostratigraphic sections, oceanic island arcs, active continental-margin calcalkaline igneous suites, and HP/UHP metamorphic terranes are manifestations of the operation of modern, Wilsoncycle plate-tectonic processes - reflecting the stately convection of enormous, large-aspect-ratio mantle cells. Rifted, transcurrent faulted, and imbricate-thrust-stacked crustal complexes also attest to divergent, transform, and convergent motions, respectively of the lithospheric plates, as do sites and architectures of sedimentary basins, orogenic belts, and terrane amalgams. The generation of oceanic plateaus, large mafic igneous provinces, and oceanic island chains characterized by positive thermal anomalies (Putirka 2008) attest to the continued existence of broad-scale mantle plumes (French and Romanowicz 2015) and bottomup mantle overturn.

Late Proterozoic-Phanerozoic contractional mountain belts form near active continental edges and island arcs. All reflect the convergence of lithospheric plates attending subduction of oceanic crust and the transport + accretion of spreading centers, oceanic plateaus, island arcs, microcontinents, and/or salients of continental crust. Long-continued underflow builds a landward calcalkaline volcanic-plutonic arc on the nonsubducted plate (DePaolo 1981; Drummond and Defant 1990; Hawkesworth et al. 1993; Clift et al. 2001; Hickey-Vargas et al. 2002), and a seaward trench complex (Ernst 1971; Miyashiro 1972; Frey et al. 1974; Maruyama et al. 1996). Brief episodes of plate convergence, such as result from underflow of a small intervening ocean basin, also produce an outboard subduction complex, but an inboard volcanic-plutonic belt is only incipiently formed or fails to develop, because substantial tracts of oceanic lithosphere must be subducted in order to form the plumbing system required to generate a continental-margin arc and new sialic crust. Although they share many features, no two orogenic belts are identical. Some collisional terranes contain rare, scattered mineralogic relics reflecting an early stage of UHP metamorphism (Chopin 1984; Smith 1984; Sobolev and Shatsky 1990; Coleman and Wang 1995; Liou et al. 1998; Liu et al. 2004), but because of thorough retrogression during exhumation, many other sutured convergent complexes that may have been subjected to similar P-T conditions no longer retain evidence of an earlier UHP event. 
A broad continuum of intermediate crustal architectures thus links two distinct kinds of mountain building (Bally 1981; Ernst 2005). (i) Alpine-type orogens form during subduction of a geographically narrow tract of oceanic lithosphere lying between two sialic blocks, resulting in continental collision. Characterized by an imbricate sequence of oceanward-verging nappes, some Alpine-type orogens also exhibit superimposed late-stage back thrusting. Metamorphism of deeply subducted portions of continental terranes ranges from moderately high-pressure to UHP. Alpine orogens are not commonly accompanied by a coeval calcalkaline arc, reflecting the incomplete development of a magmatic plumbing system. (ii) Pacific-type belts, in contrast, develop within and landward from long-sustained oceanic subduction zones. They consist of an outboard trench-forearc amalgam, and a massive inboard calcalkaline arc. The subducted oceanic section recrystallized under HP conditions, and fold vergence is chiefly oceanward. Consisting dominantly of metaluminous, I-type intermediate igneous rocks, the roughly coeval volcanic-plutonic arc sits on the nonsubducted plate landward from the trench complex. In the arc, associated metamorphic wall rocks are of the high-T/low-P type.

Wilson cycles of Phanerozoic Pacific and Alpine convergent growth of granitic crust have lithologic analogues in Archean-Early Proterozoic basement terranes. Modern outboard subduction zone-inboard calcalkaline arcs and continental collision belts exhibit similarities to ancient granite-greenstone belts and TTG terranes of the high-T early Earth (Kröner 1981; Condie 1982; Sleep 1992; Windley 1995; Ernst 2007; Brown 2008; Nutman et al. 2015). If this inferred relationship is correct, the scales, dynamics, and thermal structures of the crust-mantle system have gradually evolved in response to planetary cooling, but the controlling processes of mantle circulation, lithosphere generation, and plate tectonics have changed mainly in degree, not in kind. The high-T thermal structure of the early Earth disfavored the Archean production of alkaline igneous rocks, blueschists, and low-T eclogites; in contrast, it generated refractory komatiitic lavas, greenstone ribbon belts and gray tonalitic gneiss terranes.

\section{PLATE-TECTONIC EVOLUTION OF THE EARTH}

We infer four stages in the continuum of thermo-gravitationally driven mantle overturn, plate scales + dimensions (i.e., aspect ratios), and asthenosphere-lithosphere couplings, as typifying the Earth over geologic time (Smith 1981; Kröner 1981; Goodwin 1981a, b; Condie 1982, 2005; Ernst 2007; Sleep 2007). Progressing from early to late, these postulated stages reflect the declining planetary heat budget: (i) The Hadean stage (4.5-4.4 Ga) was attended by a near-surface magma ocean, and the consolidation of a thin, ephemeral rocky rind as surface temperatures fell well below the peridotite and basalt solidi. Reflecting viscous drag, poorly organized, rapid convection re-inserted thin platelets into the hotter mantle, completely recycling and obliterating any rock record of the former magma ocean. (ii) This condition gave way to the Hadean-Archean stage (4.4-2.7 Ga) in which the Earth's surface was covered by small, soft, hot, weakly subductable platelets. Decompression partial fusion of upwelling mantle as abundant, deep-seated, rising 
plumes generated thick sections of basaltic crust (Sleep and Windley 1982); shallow return flow and nearsurface partial fusion of the basaltic crust produced granite-greenstone belts and TTG complexes, none of which survived prior to $\sim 4.03$ (or perhaps $\sim 4.28$ ) Ga. The collision and amalgamation of these lithotectonic entities resulted in the first arcs and small protocontinents. (iii) Continued growth of granitic crust near the end of the Archean gradually led to a Proterozoic supercontinental stage (2.7-1.0 Ga) involving the development of broad continental platforms, emergence of crustal freeboard + coeval sedimentary differentiation, as well as to intracontinental orogenic belts (such as ancient analogues of the Paleozoic Altaids; Şengör et al. 1993; Şengör and Natal'in 1996). Construction and retention of large, buoyant, sialcapped lithospheric plates caused temporally limited stagnant-lid convection in the underlying, heating mantle, followed by continental break-up and drifting. Biogenically mediated increase in $\mathrm{O}_{2}$ content of the atmosphere raised the oxidation state of the crust \pm parts of the uppermost mantle. Sequestration of $\mathrm{CO}_{2}$ in marine sediments and in altered oceanic crust, combined with episodic transpolar drift of supercontinental assemblies resulted in terrestrial glaciation (Holland 1984, 1994, 2002; Melezhik et al. 2005). (iv) Attending lateral broadening of the capping lithospheric plates, and thus of much larger asthenospheric convection cells, a Late Proterozoic-Phanerozoic stage (1.0 Ga-present) of modern-style plate tectonics gradually arose. It involved crustal development through the formation of long, subparallel outboard high-P/low-T subduction-zone complexes and inboard high-T/low-P volcanic-plutonic arcs.

Inferred relationships are shown schematically in Figure 6, emphasizing a transitional, gradually increasing breadth and thickness of the Earth's lithospheric plates. Attending thermal relaxation, early planetary stages were typified by rapid ascent of deep-seated mantle plumes and vigorous circulation of hot asthenosphere, reflecting heterogeneous mantle heat sources. Over time and progressive lateral enlargement + thickening of the lithospheric plates, convective overturn began to be controlled by the sinking of dense, negatively buoyant oceanic plates. Mantle circulation in the early Earth was rapid, liberating vast amounts of heat at the terrestrial surface, whereas over geologic time, the gradual transition to larger, laminar flowing convection cells became driven more completely by descent of increasingly dense oceanic slabs, and by the near-surface stabilization of chemically buoyant continental lithosphere.

\section{GEOLOGIC SUMMARY}

In the early Earth, advective heat transfer in the mantle was dominated by hot, rising asthenosphere and incipiently melted mantle plumes, reflecting bottom-up driven mantle overturn. By $\sim 4.4 \mathrm{Ga}$, patches of a rocky scum had solidified, and primitive platelet tectonics began. Due to elevated geothermal gradients, high degrees of decompression partial melting of ascending Archean mantle plumes generated komatiitic lavas and locally thick sections of oceanic crust \pm oceanic plateaus. Platelet descent occurred in P-T regimes too hot to generate HP/UHP complexes in the downgoing lithospheric slabs. Over time, mantle flow typified by the differential transport of rapidly moving platelets gradually gave way to more rigid capping plates and 
to mantle circulation cells of increasing lateral dimensions. Cooling cratonal plates became thicker and chemically more buoyant, reflecting accumulated sialic products of crust-mantle differentiation. Accretion of supercontinental assemblies led to limited, episodic stagnant-lid behavior in the heating subcontinental mantle. Oceanic crust-capped plates concurrently became cooler and thicker, and were typified by increasingly negative buoyancy. These oceanic plates began to control the sizes and dynamics of circulating asthenospheric cells through top-down mantle overturn. Restriction of chemically-mineralogically mature sediments and intact ophiolites \pm alkali basalts to Proterozoic and younger crust, and of blueschist + low-T eclogite belts and UHP continental collisional complexes to ages of $\sim 0.75 \mathrm{Ga}$ and younger crust reflects emergence of the modern Wilson-cycle of plate tectonics, involving the underflow of relatively cool, negatively buoyant oceanic lithosphere. Generation and suturing of convergent margin crustal terranes has resulted from at least shallow subduction since incipient, fragmentary preservation of the terrestrial rock record at $\sim 4.0 \mathrm{Ga}$; the plate-tectonic process is supported by the existence of amalgamated Archean oceanic and calcalkaline arc belts, and by the collision-accretion of sialic terranes. Phanerozoic Pacific and Alpine convergent orogens have early Earth plate-tectonic analogues in granite-greenstone belts and in tonalitic gneiss terranes, respectively.

\section{ACKNOWLEDGMENTS}

This synthesis is dedicated to Kevin Burke and John Dewey, two of the most insightful, articulate leaders of the plate-tectonic revolution. Their seminal applications of global tectonics to the home planet have lighted the way for us all. Our paper is based on the accomplishments of many Earth scientists. It was support by Stanford University and by Tohoku University in part by grants from the MEXT/JSPS

KAKENHI (24403010, 15H05212) awarded to Tsujimori. Steve Shirey and Mark Harrison provided critical feedback on the draft manuscript. Editor Ali Polat, reviewer Shige Maruyama and an anonymous reviewer gave helpful criticism during the journal review. The authors thank these researchers and institutions for their advice and help.

\section{REFERENCES}

Abbott, D., Burgess, L., Longhi, J., and Smith, W.H.F., 1994. An empirical thermal history of the Earth's upper mantle. Journal of Geophysical Research, 99: 13,835-13,850.

Abe, Y., 1997. Thermal and chemical evolution of the terrestrial magma ocean. Physics of the Earth and Planetary Interiors, 100: 27-39.

Amelin, Y., Lee, D.C., Halliday, A.N., and Pidgeon, R.T., 1999. Nature of the Earth's earliest crust from hafnium isotopes in single detrital zircons. Nature, 399: 252-255.

Amelin, Y, Krot, A. N., Hutcheon, I. D., and Ulyanov, A. A., 2002. Lead isotopic ages of chondrules and calciumaluminum-rich inclusions. Science, 297: 1678-1683.

Anderson, D.L., 1987. Thermally induced phase changes, lateral heterogeneity of the mantle, continental roots, and deep slab anomalies. Journal of Geophysical Research, 90: 13,965-13,980. 
Anderson, D.L., 2001. Top-down tectonics. Science, 293: 2016-2018.

Anderson, D.L., 2005. Scoring hotspots: The plume and plate paradigms. In: Foulger, G.R., Natland, J.H., Presnall, D.C., Anderson, D.L. (Eds.), Plates, Plumes, and Paradigms. Geological Society of America Special Paper 388: 31-54.

Anderson, D. L., and Natland, J. H., 2014. Mantle updrafts and mechanisms of oceanic volcanism. Proceedings of the National Academy of Sciences, 111, no. 41: E4298-E4304.

Araki, T., Enomoto, S., Furuno, K., 2005. Gando, Y., Ichimura, K., Ikeda, H., Inoue, K., Kishimoto, Y., Koga, M., Koseki, Y., Maeda, T., Mitsui, T., Motoki, M., Nakajima, K., Ogawa, H., Ogawa, M., Owada, K., Ricol, J.S., Shimizu, I., Shirai, J., Suekane, F., Suzuki, A., Tada, K., Takeuchi, S., Tamae, K., Tsuda, Y., Watanabe, H., Busenitz, J., Classen, T., Djurcic, Z., Keefer, G., Leonard, D., Piepke, A., Yakushev, E., Berger, B.E., Chan, Y.D., Decowski, M.P., Dwyer, D.A., Freedman, S.J., Fujikawa, B.K., Goldman, J., Gray, F., Heeger, K.M., Hsu, L., Lesko, K.T., Luk, K.B., Murayama, H., O'Donnell, T., Poon, A.W.P., Steiner, .HM., Winslow, .LA., Mauger, C., McKeown, R.D., Vogel, P., Lane, C.E., Miletic, T., Guillian, G., Learned, JG., Maricic, J., Matsuno, S., Pakvasa, S., Horton-Smith, G.A., Dazeley, S., Hatakeyama, S., Rojas, A., Svoboda, R., Dieterle, B.D., Detwiler, J., Gratta, G., Ishii, K., Tolich, N., Uchida, Y., Batygov, M., Bugg, W., Efremenko, Y., Kamyshkov, Y., Kozlov, A., Nakamura, Y., Karwowski, H.J., Markoff, D.M., Nakamura, K., Rohm, R.M., Tornow, W., Wendell, R., Chen, M.J., Wang, Y.F., and Piquemal, F., 2005. Experimental investigation of geologically produced antineutrinos with KamLAND. Nature, 436: 499-503.

Arculus, R.J., 1981. Island arc magmatism in relation to the evolution of the crust and mantle. Tectonophysics, 75 : 113-133.

Armstrong, R.L., 1968. A model for the evolution of strontium and lead isotopes in a dynamic earth. Reviews in Geophysics, 6: 175-199.

Armstrong, R.L., 1981. Radiogenic isotopes: The case for crustal recycling on a near steady-state no-continentalgrowth earth. Philosophical Transactions of the Royal Society of London, A Mathematics and Physical Sciences, A301: 443-472.

Artemieva, I.M., and Mooney, W.D., 2001. Thermal thickness and evolution of Precambrian lithosphere: A global study. Journal of Geophysical Research, 106: 16,387-16,414.

Aspler, L.B., and Chiarenzelli, J.R., 1998. Two Neoarchean supercontinents? Evidence from the Paleoproterozoic. Sedimentary Geology, 120: 75-104.

Baer, A.J., 1981a. Geotherms, evolution of the lithosphere and plate tectonics. Tectonophysics, 72: 203-227.

Baer, A.J., 1981b. A Grenvillian model of Proterozoic plate tectonics. In: Kröner, A. (Ed.), Precambrian Plate Tectonics. Elsevier, Amsterdam, 353-385.

Bailey, D.K., and Woolley, A.R., 2005. Repeated, synchronous magmatism within Africa: Timing, magnetic reversals, and global tectonics. In: Foulger, G.R., Natland, J.H., Presnall, D.C., Anderson, D. L. (Eds.), Plates, Plumes, and Paradigms. Geological Society of America Special Paper 388: 365-377.

Bally, A.W., 1981. Thoughts on the tectonics of folded belts. In: Price, N.J, McClay, K. (Eds.), Thrust and Nappe Tectonics. Geological Society of London, Special Publication 9: 13-32. 
Bellini, G., Benziger, J., Bick, D., Bonfini, G., Bravo, D., Avanzini, M.B., Caccianiga, B., Cadonati, L., Calaprice, F., Cavalcante, P. and others (Borexino Collaboration), 2013. Measurement of geo-neutrinos from 1353 days of Borexino. Physics Letters B, 722: 295-300.

Birch, F., 1965. Speculations of the Earth's thermal history. Geological Society of America Bulletin, 76: 133-154.

Bleeker, W., 2002. Archean tectonics: A review with illustrations from the Slave craton. Geological Society of London, Special Publication 199: 151-181.

Bleeker, W., 2003. The late Archean record: A puzzle in ca. 35 pieces. Lithos, 71: 99-134.

Boak, J.L., and Dymek, R.F., 1982. Metamorphism of the ca. 3800 Ma supracrustal rocks at Isua, west Greenland: implications for early Archean crustal evolution. Earth and Planetary Science Letters, 59: 155-176.

Boettcher, A.L., 1973. Volcanism and orogenic belts - the origin of andesites. Tectonophysics, 17: 223-240.

Boniface, N., Schenk, V., and Appel, P., 2012. Paleoproterozoic eclogites of MORB-type chemistry and three Proterozoic orogenic cycles in the Ubendian belt (Tanzania): Evidence from monazite and zircon geochronology, and geochemistry. Precambrian Research, 192-195: 16-33.

Bottke, W. F., Vokrouhlicky, D., Marchi, S., Swindle, T., Scott, E. R., Weirich, J. R., and Levison, H., 2015, Dating the Moon-forming impact event with asteroid meteorites. Science, 348: 321-323.

Bowen, N.L., 1928. The Evolution of the Igneous Rocks. Dover Publications, New York.

Bowring, S.A., and Williams, I.S., 1999. Priscoan (4.00-4.03 Ga) orthogneisses from northwestern Canada. Contributions to Mineralogy and Petrology, 134: 3-16.

Boyd, F.R., Gurney, J.J., and Richardson, S.H., 1985. Evidence for a 150-200 km thick Archaean lithosphere from diamond inclusion thermobarometry. Nature, 315: 387-389.

Boyet, M., and Carlson, R.W., 2005. ${ }^{142} \mathrm{Nd}$ evidence for early $(>4.53 \mathrm{Ga})$ global differentiation of the silicate Earth. Science, 309: 576-581.

Bradley, D.C., 2011. Secular trends in the geologic record and the supercontinent cycle. Earth-Science Reviews, 108: 16-33.

Brown, M., 2006. A duality of thermal regimes is the distinctive characteristic of plate tectonics since the Neoarchean. Geology, 34: 961-964.

Brown, M., 2007. Metamorphic conditions in orogenic belts: a record of secular change. International Geology Review, 49: 193-234.

Brown, M., 2008. Characteristic thermal regimes of plate tectonics and their metamorphic imprint throughout Earth history: when did Earth first adopt a plate tectonics mode of behavior? In: Condie, K. C., and Pease, V., (Eds.), When Did Plate Tectonics Begin on Planet Earth? Geological Society of America Special Paper 440: 97-128.

Brounce, M., Kelley, K.A., Cottrell, E., Reagan, M.K., 2015. Temporal evolution of mantle wedge oxygen fugacity during subduction initiation. Geology, 43: 775-778.

Cameron, A.G.W., 1978. Physics of the primitive solar disk. Moon and Planets, 18: 5-40.

Cameron, A.G.W., and Benz, W., 1991. Origin of the Moon and the single impact hypothesis IV. Icarus, 92: 204-216. 
Carlson, R. W., Borg, L. E., Gaffney, A. M., and Boyet, M., 2014. Rb-Sr, Sm-Nd and Lu-Hf isotope systematics of the lunar Mg-suite: the age of the lunar crust and its relation to the time of Moon formation. Philosophical Transactions of the Royal Society, A372: 20130246; DOI: 10.1098/rsta.2013.0246.

Cates, N. L., Ziegler, K., Schmitt, A. K., and Mojzsis, S. J., 2013. Reduced, reused and recycled: detrital zircons define a maximum age for the Eoarchean (ca. 3750-3780Ma) Nuvvuagittuq Supracrustal Belt, Québec (Canada). Earth and Planetary Science Letters, 362: 283-293.

Catling, D. C., Claire, M. W., and Zahnle, K. J., 2007. Anaerobic methanotrophy and the rise of oxygen. Philosophical Transactions of the Royal Society, A365: 1867-1888.

Cawood, P. A., Kröner, A., and Pisarevsky, S., 2006. Precambrian plate tectonics: Criteria and evidence. GSA Today, 16, no. 7: 4-11.

Cawood, P. A., Hawksworth, C. J., and Dhuime, B., 2013. The continental record of generation of continental crust. Geological Society of America Bulletin, 125: 14-32.

Chopin, C., 1984. Coesite and pure pyrope in high-grade blueschists of the Western Alps. A first record and some consequences. Contributions to Mineralogy and Petrology, 86: 107-118.

Clark, S.P., and Ringwood, A.E., 1964. Density distribution and constitution of the mantle. Reviews of Geophysics, 2 : 35-88.

Clift, P.D., Rose, E.F., Shimizu, N., Layne, G.D., Draut, A.E., and Regelous, M., 2001. Tracing the evolving flux from the subducting plate in the Tonga-Kermadec arc system using boron in volcanic glass. Geochimica et Cosmochimica Acta, 65: 3347-3364.

Coleman, R. G., Lee, D. E., Beatty, L. B., and Brannock, W. W., 1965. Eclogites and eclogites; their differences and similarities. Geological Society of America Bulletin, 76: 483-508.

Coleman, R.G., and Wang, X., 1995. Overview of the geology and tectonics of UHPM. In: Coleman, R.G., Wang, X., (Eds.), Ultrahigh Pressure Metamorphism. Cambridge University Press, New York, 1-32.

Compston, W., and Pigeon, R.T., 1986. Jack Hills, evidence of more very old detrital zircons in western Australia. Nature, 321: 766-769.

Condie, K.C., 1980. Origin and early development of the Earth's crust. Precambrian Research, 11: 183-197.

Condie, K.C., 1982. Plate Tectonics and Crustal Evolution. Pergamon Press, New York, 310p.

Condie, K.C., 1994. Greenstones through time. In Condie, K.C. (Ed.), Archean Crustal Evolution. Elsevier, Amsterdam, 85-120.

Condie, K.C., 1998. Episodic continental growth and supercontinents: A mantle avalanche connection? Earth and Planetary Science Letters, 163: 97-108.

Condie, K.C., 2005. Earth as an Evolving Planetary System. Academic Press, Amsterdam, 447p.

Condie, K. C., 2007. Accretionary orogens in time and space: In: Hatcher, R. D., Jr., Carlson, M. P., McBride, J. H., Martínez. Catalán, (Eds.), 4-D Framework of Continental Crust. Geological Society of America Memoir 200, 145-158.

Condie, K. C., and Kröner, A., 2013. The building blocks of continental crust: Evidence for a major change in the tectonic setting of continental growth at the end of the Archean. Gondwana Research, 23: 394-402. 
Condie, K.C., Davaille, A., Aster, R.C., and Arndt, N., 2015. Upstairs-downstairs: supercontinents and large igneous provinces, are they related? International Geology Review, 57: 1341-1348.

Conrad, C.P., and Lithgow-Bertelloni, C., 2002. How mantle slabs drive plate tectonics. Science, 298: 207-209.

Cook, F.A., van der Velden, A.J., Hall, K.W., and Roberts, B.J., 1999. Frozen subduction in Canada's Northwest Territories: Lithoprobe deep lithospheric reflection profiling of the western Canadian shield. Tectonics, 18: 1-24.

Crameri, F., Tackley, P. J., Meilick, I., Gerya, T. V., and Kaus, B. J. P., 2012. A free plate surface and weak oceanic crust produce single-sided subduction on Earth. Geophysical Research Letters, 39: L03306, doi:10.1029/2011GL050046, 7p.

Davies, G. F., 1980. Thermal histories of convective Earth models and constraints on radiogenic heat production in the Earth. Journal of Geophysical Research, 85: 2517-2530.

Davies, G.F., 1992. On the emergence of plate tectonics. Geology, 20: 963-966.

Davies, G.F., 1993. Conjectures on the thermal and tectonic evolution of the earth. Lithos, 30: 281-289.

Davies, G.F., 1999. Dynamic Earth: Plates, Plumes, and Mantle Convection. Cambridge University Press, New York.

Davies, G. F., 2006. Gravitational depletion of the early Earth's upper mantle and the viability of early plate tectonics. Earth and Planetary Science Letters, 243: 376-382.

Davies, G. F., 2007. Controls on density stratification in the early mantle. Geochemistry Geophysics Geosystems, 8: Q04006, doi: 10.1029/2006GC001414.

Davies, G. F., 2009. Effect of plate bending on the Urey ratio and the thermal evolution of the mantle. Earth and Planetary Science Letters, 287: 513-518.

DePaolo, D.J., 1981. Nd isotopic studies: some new perspectives on Earth structure and evolution. Transactions of the American Geophysical Union, 62: 137-140.

DePaolo, D. J., Linn, A. M., and Schubert, G., 1991. The continental crustal age distribution: Methods of determining mantle separation ages from Sm-Nd isotopic data and application to the southwestern United States. Journal of Geophysical Research, 96: 2071-2088.

De Paoli, M.C., Clarke, G.L., Klepeis, K.A., Allibone, A.H., and Turnbull, I.M., 2009. The eclogite-granulite transition: mafic and intermediate assemblages at Breaksea Sound, New Zealand. Journal of Petrology, 50: 23072343.

Dewey, J. F., 2007. The secular evolution of plate tectonics and the continental crust: An outline. In: Hatcher, R. D., Jr., Carlson, M. P., McBride, J. H., Martínez. Catalán, (Eds.), 4-D Framework of Continental Crust. Geological Society of America Memoir 200: 1-7.

Diener, J., Stevens, G., and Kisters, A., 2006. High-pressure intermediate-temperature metamorphism in the Southern Barberton granitoid-greenstone terrain, South Africa: A consequence of subduction-driven overthickening and collapse of mid-Archean continental crust. In Benn, K., Mareschal, J.C., Condie, K.C., (Eds.), Archean Geodynamics and Environments. Geophysical Monograph Series, 164: 239-254, AGU, Washington, D.C.

Dilek, Y., and Polat, A., 2008. Suprasubduction zone ophiolites and Archean tectonics. Geology, 36: 431-432.

Dilek, Y., 2003. Ophiolite pulses, orogeny, and mantle plumes. Geological Society of London Special Publications 218: 9-19. 
Dobrzhinetskaya, L., Wirth, R., and Green, H., 2014. Diamonds in Earth’s oldest zircons from Jack Hills conglomerate, Australia, are contamination. Earth and Planetary Science Letters, 387: 212-218.

Drummond, M.S., and Defant, M.J., 1990. A model for trondhjemite-tonalite-dacite genesis and crustal growth via slab melting: Archean to modern comparisons. Journal of Geophysical Research, 95: 21,503-21,521.

Dufek, J., and Bergantz, G.W., 2005. Lower crustal magma genesis and preservation: a stochastic framework for the evaluation of basalt-crust interaction. Journal of Petrology, 46: 2167-2195.

Dye, S. T., (Ed.), 2007, Neutrino Geophysics: Proceedings of Neutrino Sciences 2005: Dordrecht, The Netherlands: Springer. doi:10.1007/978-0-387-70771-6. ISBN 978-0-387-70766-2.

Elkins-Tanton, L., 2008. Linked magma ocean solidification and atmospheric growth for Earth and Mars. Earth and Planetary Science Letters, 271: 181-191.

Elsasser, W.M., 1963. Early history of the Earth. In: Geiss, J., Goldbert, E. (Eds.), Earth Science and Meteorites. North Holland Publishing Company, Amsterdam, 1-30.

Ernst, W.G., 1971. Metamorphic zonations on presumably subducted lithospheric plates from Japan, California, and the Alps. Contributions to Mineralogy and Petrology, 34: 43-59.

Ernst, W.G., 1972. Occurrence and mineralogic evolution of blueschist belts with time. American Journal of Science, 272: $657-668$.

Ernst, W.G., 1983. The early Earth and Archean rock record. In: Schopf, J.W. (Ed.), The Earth's earliest Biosphere: Its Origin and Evolution. Princeton University Press, Princeton, 41-52.

Ernst, W.G., 1999. Hornblende, the continent maker-Evolution of $\mathrm{H}_{2} \mathrm{O}$ during circum-Pacific subduction versus continental collision. Geology, 27: 675-678.

Ernst, W.G., 2005. Alpine and Pacific styles of Phanerozoic mountain building: subduction-zone petrogenesis of continental crust. Terra Nova, 17: 165-188.

Ernst, W. G., 2007. Speculations on evolution of the terrestrial lithosphere-asthenosphere system-Plumes and plates. Gondwana Research, 11: 38-49.

Flaser, F.M., and Birch, F., 1973. Energetics of core formation: a correction. Journal of Geophysical Research, 78: 6101-6103.

Foley, B. J., Bercovici, D., and Elkins-Tanton, L. T., 2014. Initiation of plate tectonics from post-magma ocean thermochemical convection. Journal of Geophysical Research, Solid Earth, 119: 8538-8561, doi:10.1002/2014JB011121.

French, S.W., Romanowicz,m 2015.Broad plumes rooted at the base of the Earth's mantle beneath major hotspots. Nature, 525: 95-99 doi:10.1038/nature14876

Frey, M., Hunziker, J.C., Frank, W., Bocquet, J., Dal Piaz, G.V., Jäger, E., and Niggli, E., 1974. Alpine metamorphism of the Alps. Schweizerische Mineralogisches und Petrografisches Mittelungen, 54: 248-290.

Furnes, H., de Witt, M., Staudigel, H., Rosing, M., and Muehlenbachs, K., 2007. A vestige of Earth's oldest ophiolite. Science, 315: 1704-1707.

Ganne, J., de Andrade, V., Weinberg, R.F., Vidal, O., Dubacq, B., Kagambega, N., Naba, S., Baratoux, L., Jessell, M., and Allibon, J., 2012. Modern-style plate subduction preserved in the Palaeoproterozoic West African craton. 
Nature Geoscience, 5: 60-65.

Garde, A.A., 2007. A Mid-Archean island arc complex in the eastern Akia terrane, Godthåbsfjord, southern West Greenland. Journal of the Geological Society, London, 164, 565-579.

Golabek, G. J., Schmeling, H., and Tackley, P. J., 2008. Earth's core formation aided by flow channeling instabilities induced by iron diapirs. Earth and Planetary Science Letters, doi: 10.1016/j.eps1.2008.02.033

Goodwin, A.M., 1981a. Archean plate tectonics and greenstone belts. In: Kröner, A. (Ed.), Precambrian Plate Tectonics. Elsevier, Amsterdam, 105-135.

Goodwin, A.M., 1981b. Precambrian perspectives. Science, 213: 55-61.

Green, D.H., 1975. Genesis of Archean peridotitic magmas and constraints on Archean geothermal gradients and tectonics. Geology, 3: 15-18.

Green, D.H., 1981. Petrogenesis of Archean ultramafic magmas and implications for Archean tectonics. In: Kröner,

A. (Ed.), Precambrian Plate Tectonics. Elsevier, Amsterdam, 469-489.

Green, D.H., and Ringwood, A.E., 1967. An experimental investigation of the gabbro to eclogite transformation and its petrological applications. Geochimica et Cosmochimica Acta, 31: 767-833.

Griffin, W. L., Belousova, E. A., O’Neill, C. O., O’Reilly, S. Y., Malkovets, V., Pearson, N. J., Spetsius, S., and Wilde, S. A., 2014. The world turns over: Hadean-Archean crust-mantle evolution: Lithos, 189: 2-15.

Grove, T.L., and Parman, S.W., 2004. Thermal evolution of the Earth as recorded by komatiites. Earth and Planetary Science Letters, 219: 173-187.

Gurnis, M., 1988. Large-scale mantle convection and the aggregation and dispersal of supercontinents. Nature, 332: 695-699.

Halliday, A.N., 2004. Mixing, volatile loss and compositional change during impact-driven accretion of the Earth. Nature, 427: 505-509.

Hamilton, W.B., 1998. Archean magmatism and deformation are not the products of plate tectonics. Precambrian Research, 91: 143-179.

Hamilton, W.B., 2003. An alternative Earth. GSA Today, 13, no. 11: 4-12.

Hamilton, W. B., 2007. Earth's first two billion years - The era of internally mobile crust. In: Hatcher, R. D., Jr., Carlson, M. P., McBride, J. H., Martínez. Catalán, (Eds.), 4-D Framework of Continental Crust. Geological Society of America Memoir 200: 233-296.

Hansen, V. L., 2007. Subduction origin on early Earth: A hypothesis. Geology, 35: 1059-1062.

Hargraves, R.B., 1981. Precambrian tectonic style: a liberal uniformatarian interpretation. In: Kröner, A. (Ed.), Precambrian Plate Tectonics. Elsevier, Amsterdam, 21-56.

Harrison, T. M., 2009. The Hadean crust: evidence from >4 Ga zircons. Annual Review of Earth and Planetary Sciences, 37: 479-505. (doi:10.1146/annurev.earth.031208.100151)

Harrison, T.M., Blichert-Toft, J., Müller, W., Albarede, F., Holden, P., Mojzsis, S.J., 2005. Heterogeneous Hadean hafnium: evidence of continental crust at 4.4 to $4.5 \mathrm{Ga}$. Science, 310: 1947-1950.

Harrison, T.M., Schmitt, A.K., McCulloch, M. T., Lovera, O. M., 2008. Early ( 4.5 Ga) formation of terrestrial crust; Lu-Hf, 8180 , and Ti thermometry results for Hadean zircons. Earth and Planetary Science Letters, 268: 476-486. 
Hawkesworth, C.J., Gallagher, K., Hergt, J.M., and McDermott, F., 1993. Mantle and slab contributions in an arc magma. Annual Review of Earth and Planetary Sciences, 21: 175-204.

Hawkesworth, C.J., Cawood, P., Dhuime, B., 2013. Continental growth and the crustal record. Tectonophysics, 609: 651-660.

Hazen, R. M., Papineau, D., Bleeker, W., Downs, R. T., Ferry, J. M., McCoy, T. J., Sverjensky, D., and Yang, H., 2008. Mineral evolution. American Mineralogist, 93: 1693-1720.

Head, J.W., and Solomon, S.C., 1981. Tectonic evolution of the terrestrial planets. Science, 213: 62-76.

Herzberg, C.T., 1987. Magma density at high pressure. Part 1: the effect of composition on the elastic properties of silicate liquids. Part 2: a test of the olivine flotation hypothesis. In: Mysen, B.O. (Ed.), Magmatic Processes: Physicochemical Principles. Geochemical Society Special Publication 1: 25-58.

Herzberg, C., Condie, and K., Korenaga, J., 2010. Thermal history of the Earth and its petrological expression. Earth and Planetary Science Letters, 292: 79-88. (doi:10.1016/j.eps1.2010.01.022)

Hickey-Vargas, R., Sun, M., Lopez-Escobar, L., Moreno-Roa, H., Reagan, M.K., Morris, J.D., and Ryan, J.G., 2002. Multiple subduction components in the mantle wedge: Evidence from eruptive centers in the Central Southern volcanic zone, Chile. Geology, 30: 199-202.

Hill, R.E.T, and Boettcher, A.L., 1970. Water in the Earth's mantle: melting curves of basalt-water and basalt-watercarbon dioxide. Science, 167: 980-982.

Holland, H.D., 1984. The Chemical Evolution of the Atmosphere and Oceans. Princeton University Press, Princeton, $582 \mathrm{p}$.

Holland, H.D., 1994. Early Proterozoic atmospheric change. In: Bergtson, S. (Ed.), Early Life on Earth. Columbia University Press, New York, 237-244.

Holland, H.D., 2002. Volcanic gases, black smokers, and the great oxidation event. Geochimica et Cosmochimica Acta, 66: 3811-3826.

Holloway, J.R., and Burnham, C.W., 1972. Melting relations of basalt with equilibrium water pressure less than total pressure. Journal of Petrology, 13: 1-29.

Hopkins, M., Harrison, T. M., and Manning, C. E., 2008. Low heat flow inferred from $>4$ Gyr zircons suggests Hadean plate boundary interactions. Nature, 456: 493-496.

Hopkins, M., Harrison, T. M., and Manning, C. E., 2010. Constraints on Hadean geodynamics from mineral inclusions in $>4 \mathrm{Ga}$ zircons. Earth and Planetary Science Letters, 298: 367-376.

Hutchison, R., Williams, I.P., and Russell, S.S., 2001. Theories of planetary formation: constraints from the study of meteorites. Philosophical Transactions of the Royal Society of London, 359: 2077-2093.

Hynes, A., 2008, Effects of a warmer mantle on the characteristics of Archean passive margins. In: Condie, K. C., Pease, V., (Eds.), When Did Plate Tectonics Begin on Planet Earth? Geological Society of America Special Paper 440: 149-156.

Irifune, T., 1993. Phase transformations in the earth's mantle and subducting slabs: Implications for the compositions, seismic velocity and density structures, and dynamics. The Island Arc, 2: 55-71. 
Ito, K., and Kennedy, G.C., 1967. Melting and phase relations in a natural peridotite to 40 kilobars. American Journal of Science, 265: 519-538.

Jackson, J., McKenzie, D., Priestley, K., and Emmerson, B., 2008. New views on the structure and rheology of the lithosphere. Journal of the Geological Society of London, 165: 453-465.

Jacob, D.E., 2004. Nature and origin of eclogite xenoliths from kimberlites. Lithos, 77: 295-316.

Jacobson, S.B., Wasserburg, G.J., 1981. Transport models for crust and mantle evolution. Tectonophysics, 75: 163179.

Kasting, J.F., 2001. The rise of atmospheric oxygen. Science, 293: 819-820.

Kaula, W.M., 1979. Thermal evolution of Earth and Moon growing by planetesimal impacts. Journal of Geophysical Research, 84: 999-1008.

Kennedy, C. S., and Kennedy, G. C., 1976. The equilibrium boundary between graphite and diamond. Journal of Geophysical Research, 81: 2467-2470.

Kisters, A.F.M., van Hinsberg, V.J., Szilas, K., 2012. Geology of an Archaean accretionary complex — the structural record of burial and return flow in the Tartoq Group of South West Greenland. Precambrian Research 220-221, 107-122.

Kleine, T., Mezger, K., Palme, H., and Münker, C., 2004. The W isotope evolution of the bulk silicate EarthConstraints on the timing and mechanisms of core formation and accretion. Earth and Planetary Science Letters, 228: 109-123.

Kleine, T., Palme, H., Mezger, K., and Halliday, A.N., 2005. Hf-W chronometry of lunar metals and the age and early differentiation of the Moon. Science, 310: 1671-1674.

Komiya, T., Maruyama, S., Nohda, S., Masuda, T., Hayashi, M., and Okamoto, S., 1999. Plate tectonics at 3.8 - 3.7 $\mathrm{Ga}$; Field evidence from the Isua accretionary complex, southern West Greenland. Journal of Geology, 107: 515554.

Komiya, T., Hayashi, M., Maruyama, S., and Yurimoto, H., 2002. Intermediate-P/T type Archean metamorphism of the Isua supracrustal belt: implications for secular change of geothermal gradients at subduction zones and for Archean plate tectonics. American Journal of Science, 302: 804-826.

Komiya, T., Yamamato, S., Aoki, S., Sawaki, Y., Ishikawa, A., Tashiro, T., Koshida, K., Shimojo, M., Aoki, K., and Collerson, K.D., 2015. Geology of the Eoarchean, >3.95 Ga, Nulliak supracrustal rocks in the Saglek Block, northern Labrador, Canada: The oldest geological evidence for plate tectonics. Tectonophysics, http://dx.doi.org/10.1016/j.tecto.2015.05.003

Korenaga, J., 2006. Archean geodynamics and the thermal evolution of Earth. In: Benn, K., Mareschal, and J.-C., Condie, K., (Eds.), Archean Geodynamics and Environments, AGU Geophysical Monograph Series 164: 7-22, Washington DC.

Korenaga, J., 2008a. Plate tectonics, flood basalts, and the evolution of Earth's oceans. Terra Nova, 20: 419-439.

Korenaga, J., 2008b. Urey ratio and the structure and evolution of Earth's mantle. Reviews of Geophysics, 46: RG2007, doi:10.1029/2007RG000241. 
Korsman, K., Korja, T., Pajunen, M., Virransalo, P., and GGT/SVEKA Working Group, 1999. The GGT/SVEKA Transect: structure and evolution of the continental crust in the Palaeoproterozoic Svecofennian orogen in Finland. International Geology Review, 41: 287-333.

Krauss, L. M., Glashow, S. L., and Schramm, D. N., 1984. Antineutrino astronomy and geophysics: Nature, 310: 191-198.

Kröner, A., 1981. Precambrian plate tectonics. In: Kröner, A. (Ed.), Precambrian Plate Tectonics. Elsevier, Amsterdam, 57-90.

Kump, L. R., and Barley, M. E., 2007. Increased subaerial volcanism and the rise of atmospheric oxygen 2.5 billion years ago. Nature, 448: 1033-1036.

Kushiro, I., Syono, Y., and Akimoto, S., 1968. Melting of a peridotite nodule at high pressures and high water pressures. Journal of Geophysical Research, 73: 6023-6029.

Kusky, T.M., Li, J.H., and Tucker, R.D., 2001. The Archean Dongwanzi ophiolite complex, north China craton: 2.505 billion-year-old oceanic crust and mantle. Science, 292: 1142-1145.

Lambert, I.B., and Wyllie, P.J., 1972. Melting of gabbro (quartz eclogite) with excess water to 35 kilobars, with geological applications. Journal of Geology, 80: 693-708.

Lambert, R.St.J., 1976. Archean thermal regimes, crustal and upper mantle temperatures, and a progressive evolutionary model for the earth. In: Windley, B.F. (Ed.), The Early History of the Earth. John Wiley, New York, 363-373.

Lambert, R.St.J., 1980. The thermal history of the earth in the Archean. Precambrian Research, 11: 199-213.

Lambert, R.St.J., 1981. Earth tectonics and thermal history: review and a hot spot model for the Archean. In: Kröner, A. (Ed.), Precambrian Plate Tectonics. Elsevier, Amsterdam, 453-467.

Lee, W.H.K., 1970. On the global variation of terrestrial heat flow. Physics of Earth and Planetary Interiors, 2: 332341.

Lenardic, A., Moresi, L.N., and Mühlhaus, H., 2003. Longevity and stability of cratonic lithosphere: Insights from numerical simulations of coupled mantle convection and continental tectonics. Journal of Geophysical Research, 108: 2303, doi: 10.1029/2002JB001859, 2003.

Liou, J.G., Zhang, R.Y., Ernst, W.G., Rumble, D.III, and Maruyama, S., 1998. High pressure minerals from deeply subducted metamorphic rocks. Reviews in Mineralogy, 37: 33-96.

Liu, F., Xu, Z., Liou, J.G., and Song, B., 2004. SHRIMP U-Pb ages of ultrahigh-pressure and retrograde metamorphism of gneisses, south-western Sulu terrane, eastern China. Journal of Metamorphic Geology, 22: $315-$ 326.

Liu, J., Bohlen, S.R., and Ernst, W.G., 1996. Stability of hydrous phases in subducting oceanic crust. Earth and Planetary Science Letters, 143: 161-171.

Lowman, J.P., and Jarvis, G.T., 1996. Continental collisions in wide aspect ratio and high Rayleigh number twodimensional mantle convection models. Journal of Geophysical Research, 101: 25,485-25,497. 
Lucas, S.B., Stern, R.A., Syme, E.C., Reilly, B.A., and Thomas, D.J., 1996. Interoceanic tectonics and the development of continental crust: 1.92-1.84 Ga evolution of the Flinn Flon Belt, Canada. Geological Society of America Bulletin, 108: 602-629.

Luth, W.C., Jahns, R.H., and Tuttle, O.F., 1964. The granite system at pressures of 4 to 10 kilobars. Journal of Geophysical Research, 69: 759-773.

Mareschal, J. C., Jaupal, C., Phaneuf, C., and Perry, C. 2012. Geoneutrinos and the energy budget of the Earth. Journal of Geodynamics, 54: 43-54.

Martin, H., 1986. Effect of steeper Archean geothermal gradient on geochemistry of subduction-zone magmas. Geology, 14: 753-756.

Maruyama, S., and Liou, J.G., 2005. From snowball to Phanerozoic earth. International Geology Review, 47: 775791.

Maruyama, S., Liou, J.G., and Terabayashi, M., 1996. Blueschists and eclogites of the world, and their exhumation. International Geology Review. 38: 485-594.

Maruyama, S., Santosh, M., and Zhao, D., 2007. Superplume, supercontinent and post-perovskite: Mantle dynamics and anti-plate tectonics at the Core-Mantle Boundary. Gondwana Research, 11: 7-37.

McCulloch, M.T., and Bennett, V.C., 1994. Progressive growth of the Earth's continental crust and depleted mantle. Geochimica et Cosmochimica Acta, 58: 4717-4738.

McSween, H. Y., Jr., 2015. Mapping the planets—geology stakes its claim: GSA Today, 25, no. 1: 4-9.

Melezhik, V.A., Fallick, A.E., Hanski, E.J., Kump. L.R., Lepland, A., Prave, A.R., and Strauss, H., 2005. Emergence of the aerobic biosphere during the Archean-Proterozoic transition: Challenges of future research. GSA Today, 15, no.11: 4-11.

Menneken, M., Nemchin, A. A., Geisler, T., Pidgeon, R. T., and Wilde, S. A., 2007. Hadean diamonds in zircon from Jack Hills, Western Australia. Nature, 448: 917-921.

Mints, M.V., Belousova, E.A., Konilov, A.N., Natapov, L.M., Shchipansky, A.A., Griffin, W.L., O’Reilly, S.Y., Dokukina, K.A., and Kaulina, T.V., 2010. Mesoarchean subduction processes: 2.87 Ga eclogites from the Kola Peninsula, Russia. Geology, 38: 739-742.

Mitchell, R. N., and Korenaga, J., in review, True polar wander and the cooling Earth: Proc. Nat. Acad. Sci., -

Mitchell, R. N., Bleeker, W., van Breeman, O., Lecheminant, T.N., Peng, P., Nilsson, M.K.M., and Evans, D.A.D, 2014. Plate tectonics before $2.0 \mathrm{Ga}$ : Evidence from paleomagnetism of cratons within supercontinent Nuna: American Journal of Science, 314: 878-894, DOI 10.2475/04.2014.03

Miyashiro, A., 1961. Evolution of metamorphic belts. Journal of Petrology, 2: 277-311.

Miyashiro, A., 1972. Metamorphism and related magmatism in plate tectonics. American Journal of Science, 272: 629-656.

Mojzsis, S. J., Arrhenius, G., McKeegan, K. D., Harrison, T. M., and Nutman, A. P., 1996. Evidence for life on Earth before 3,800 million years ago. Nature, 55: 9.

Mojzsis, S.J., Harrison, T.M., and Pidgeon, R.T., 2001. Oxygen-isotope evidence from ancient zircons for liquid water at the Earth's surface 4,300 Myr ago. Nature, 409: 178-181. 
Mojzsis, S. J., Cates, N. L., Caro, G., Trail, D., Abramov, O., and Guitreau, M., 2014. Component geochronology in the polyphase ca. 3920Ma Acasta Gneiss. Geochimica et Cosmochimica Acta, 133: 68-96.

Moyen, J. F., Stevens, G., and Kisters, A., 2006. Record of mid-Archaean subduction from metamorphism in the Barberton terrain, South Africa. Nature, 442: 559-562.

Moorbath, C., 1984. Patterns and geological significance of age determinations in continental blocks. In: Holland, H.D., and Trendall, A.F. (Eds.), Patterns of Change in Earth Evolution. Dahlem Konferenzen 1984, SpringerVerlag, Berlin, 207-219.

Moorbath, C., O’Nions, R.K., Pankhurst, J.R., Gale, N.H., and McGregor, V.R., 1972. Further Rb-Sr age determinations on the Early Precambrian rocks of the Godthaab district, West Greenland. Nature, 240: 78-82.

Moresi, L., and Solomatov, V. S., 1998. Mantle convection with a brittle lithosphere: thoughts on the global tectonic styles of the Earth and Venus. Geophysical Journal International, 133: 669-682.

Mosher, S., Levine, J. S. F., and Carlson, W. D., 2008. Mesoproterozoic plate tectonics: A collisional model for the Grenville-aged orogenic belt in the Llano uplift, central Texas. Geology, 36: 55-58.

Möller, A., Appel, P., Mezger, K., and Schenk, V., 1995. Evidence for a 2 Ga subduction zone: eclogites in the Usagaran Belt of Tanzania. Geology, 23: 1067-1070.

Moyen, J-F., Stevens, G., and Kisters, A., 2006. Record of mid-Archaean subduction from metamorphism in the Barberton terrain, South Africa. Nature, 442: 559-562.

Mueller, W.U., Marquis, R., and Thurston, P., 2002. Evolution of the Archean Abitibi greenstone belt and adjacent terranes: New insights from geochronology, geochemistry, structure and facies analysis. Precambrian Research, 115: 374p.

Mysen, B.O., and Boettcher, A.L., 1975. Melting in a hydrous mantle: II geochemistry of crystals and liquids formed by anatexis of mantle peridotite with controlled activities of $\mathrm{H}_{2} \mathrm{O}, \mathrm{CO}_{2}$, and $\mathrm{O}_{2}$. Journal of Petrology, 16: 549-593.

Nair, R., and Chacko, T., 2008. Role of oceanic plateaus in the initiation of subduction and origin of continental crust. Geology, 36: 583-586.

Nelson, B.K., and DePaolo, D.J., 1984. 1,700 Myr greenstone volcanic successions in southwestern North America and isotopic evolution of Proterozoic mantle. Nature, 311: 143-146.

Nelson, B.K., and DePaolo, D.J., 1985. Rapid production of continental crust 1.7 to 1.9 b. y. ago: Nd isotopic evidence from the basement of the North American mid-continent. Geological Society of America Bulletin, 96: 746-754.

Nisbet, E. G., and Sleep, N. H., 2001. The habitat and nature of early life. Nature, 409: 1083-1091.

Nisbet, E.G., Bickle, M.J., and Martin, A., 1977. Mafic and ultramafic lavas of Belingwe greenstone belt, Rhodesia. Journal of Petrology, 18: 521-566.

Nutman, A. P., Mojzsis, S. J., and Friend, C. R. L., 1997, Recognition of $\geq 3850$ Ma water-lain sediments in West Greenland and their significance for the early Archaean Earth. Geochimica et Cosmochimica Acta, 61: 24752484.

Nutman, A.P., Friend, C.R.L., 2009. New 1:20,000 scale geological maps, synthesis and history of investigation of the Isua supracrustal belt and adjacent orthogneisses, southern West Greenland: A glimpse of Eoarchean crust 
formation and orogeny. Precambrian Research 172, 189-211.

Nutman, A.P., Bennett, V.C., Friend, C.R.L., 2015. Proposal for a continent 'Itsaqia' amalgamated at 3.66 Ga and rifted apart from $3.53 \mathrm{Ga}$ : Initiation of a Wilson Cycle near the start of the rock record. American Journal of Science 315: 509-536.

Ohta, H., Maruyama, S., Takahashi, E., Watanabe, Y., and Kato, Y., 1996. Field occurrence, geochemistry and petrogenesis of the Archean mid-oceanic ridge basalts (AMORBs) of the Cleaverville area, Pilbara craton, western Australia. Lithos, 37: 199-221.

Okamoto, K., and Maruyama, S., 1999. The high pressure synthesis of lawsonite in the MORB $+\mathrm{H}_{2} \mathrm{O}$ system. American Mineralogist, 84: 362-373.

O’Neill, C. O., and Debaille, V., 2014. The evolution of Hadean-Eoarchaean geodynamics. Earth and Planetary Science Letters, 406: 49-58.

O’Neill, C. O., Lenardic, A., Moresi, L., Torsvik, T. H., and Lee, C. T. A., 2007. Episodic Precambrian subduction. Earth and Planetary Science Letters, 262: 552-562.

O’Neil, J., Carlson, R.W., Francis, D., and Stevenson, R. K., 2008. Neodymium-142 evidence for Hadean mafic crust. Science, 321: 1828-1831.

O’Neil, J., Francis, D., and Carlson, R.W., 2011. Implications of the Nuvvuagittuq greenstone belt for the formation of Earth's early crust. Journal of Petrology, 52: 985-1009.

O’Nions, R.K., Evensen, N.M., and Hamilton, P.J., 1980. Differentiation and evolution of mantle. Proceedings of the Royal Society of London, 297: 479-493.

Oyarzun, R., Lillo, J., and Oyarzun, J., 2008. No water, no cyanobacteria—no calc-alkaline magmas: Progressive oxidation of the early oceans may have contributed to modernize island arc magmatism. International Geology Review, 50: 885-894.

Parman, S.W., Grove, T.L., and Dann, J.C., 2001. The production of Barberton komatiites in an Archean subduction zone. Geophysical Research Letters, 28: 2513-2516.

Papanastassiou, D.A., and Wasserburg, G., 1971. Lunar chronology and evolution from Rb-Sr studies of Apollo 11 and 12 samples. Earth and Planetary Science Letters, 11: 37-62.

Patterson, C.C., 1956. Age of meteorites and the earth. Geochimica et Cosmochimica Acta, 10: 230-237.

Peltonen, P., and Kontinen, A., 2004. The Jormusa Ophiolite: A mafic-ultramafic complex from an ancient oceancontinent transition zone. In Kusky, T. M., (Ed.), Precambrian Ophiolites and Related Rocks. Developments in Precambrian Geology, 13: 35-72, Elsevier, Amsterdam.

Percival, J.A., Stern, R.A., Skulski, T., Card, K.D., Mortensen, J.K., and Begin, N.J., 1994. Minto block, Superior province: Missing link in deciphering assembly of the craton at $2.7 \mathrm{Ga}$. Geology, 22: 839-842.

Perry, H. K. C., Mareschal, J.-C., and Jaupart, C., 2009. Enhanced crustal geo-neutrino production near the Sudbury Neutrino Observatory, Ontario, Canada. Earth and Planetary Science Letters, 288: 301-308.

Pertermann, M., and Hirschmann, M.M., 2003. Anhydrous partial melting experiments on MORB-like eclogite: phase relations, phase compositions and mineral-melt partitioning of major elements at 2-3 GPa. Journal of Petrology, 44: 2173-2201. 
Polat, A., Kerrich, R., Wyman, D.A., 1998. The late Archean Schreiber-Hemlo and White River-Dayohessarah greenstone belts, Superior Province: collages of oceanic plateaus, oceanic arcs, and subduction-accretion complexes. Tectonophysics 289: 295-326.

Polat, A., Hofmann, A.W., Rosing, M., 2002. Boninite-like volcanic rocks in the $3.7-3.8$ Ga Isua greenstone belt, West Greenland: Geochemical evidence for intra-oceanic subduction zone processes in the early Earth. Chemical Geology 184, 231-254.

Polat, A., Kusky, T., Li, J.H., Fryer, B., Kerrich, R., and Patrick, K., 2005. Geochemistry of Neoarchean (ca. 2.55$2.50 \mathrm{Ga}$ ) volcanic and ophiolitic rocks in the Wutaishan greenstone belt, central orogenic belt, North China craton: Implications for geodynamic setting and continental growth. Geological Society of America Bulletin, 117: 1387-1399.

Polat, A., Appel, P.W.U., Frei, R., Pan, Y., Dilek, Y., Ordonez-Calderon, J.C., Fryer, B., Hollis, J.A., and Raith, J.G., 2007. Field and geochemical characteristics of the Mesoarchean ( $3075 \mathrm{Ma})$ Ivisaartoq greenstone belt, southern West Greenland: Evidence for seafloor hydrothermal alteration in supra-subduction oceanic crust. Gondwana Research, 11: 69-71.

Polat, A., Frei, R., Appel, P. W. U., Dilek, Y., Fryer, B., Ordoñez-Calderón, J. C., and Yang, Z., 2008. The origin and compositions of Mesoarchean oceanic crust: Evidence from the 3075 Ma Ivisaartoq greenstone belt, SW Greenland. Lithos, 100: 293-321.

Poli, S., and Schmidt, M.W., 1995. $\mathrm{H}_{2} \mathrm{O}$ transport and release in subduction zones: Experimental constraints on basaltic and andesitic systems. Journal of Geophysical Research, 100: 22,299-22,314.

Pollack, H.N., 1997. Thermal characteristics of the Archaean. In De Wit, M.J., Ashwal, L.D. (Eds.), Greenstone Belts. Oxford Monographs on Geology and Geophysics, 35: 223-232.

Pope, E.C., Bird, D.K., and Rosing, M.T., 2012. Isotope composition and volume of Earth's early oceans. Proceedings of the National Academy of Sciences, 109: 4371-4376.

Presnall, D.C., and Gudfinnsson, G.H., 2005. Carbonate-rich melts in the oceanic low-velocity zone and deep mantle. In: Foulger, G.R., Natland, J.H., Presnall, D.C., and Anderson, D.L., (Eds.), Plates, Plumes, and Paradigms. Geological Society of America Special Paper 388: 207-216.

Putirka, K., 2008. Excess temperatures at ocean islands: Implications for mantle layering and convection. Geology, 36: 283-286.

Rapp, R.P., Shimizu, N., Norman, M.D., and Applegate, G.S., 1995. Reaction between slab-derived melts and peridotite in the mantle wedge: Experimental constraints at $3.8 \mathrm{GPa}$. Chemical Geology, 160: 335-356.

Reymer, A.P.S., and Schubert, G., 1986. Rapid growth of some major segments of the continental crust. Geology, 14 : 299-302.

Richardson, S. H., Gurney, J. J., Erlank, A. J., and Harris, J. W., 1984. Origin of diamonds in old enriched mantle. Nature, 310: 198-202.

Richter, F.M., 1984. Time and space scales of mantle convection. In: Holland, H.D., Trendall, A.F. (Eds.), Patterns of Change in Earth Evolution. Dahlem Konferenzen 1984, Springer-Verlag, Berlin, 271-289. 
Richter, F.M., 1988. A major change in the thermal state of the Earth at the Archean-Proterozoic boundary:

Consequences for the nature and preservation of continental lithosphere. Journal of Petrology, Special Lithos Issue: $39-52$.

Rino, S., Kon, Y., Sato, W., Maruyama, S., Santosh, M., Zhao, D., 2008. The Grenvillian and Pan-African orogens: World's largest orogenies through geologic time, and their implications on the origin of superplume, Gondwana Research, 14: 51-72.

Rogers, J.J.W., and Santosh, M., 2004. Continents and Supercontinents. Oxford University Press, New York.

Ronov, A. B., and Migdisov, A. A., 1971. Geochemical history of the crystalline basement and the sedimentary cover of the Russian and North American platforms. Sedimentology, 16: 137-185.

Rosing, M. T., Bird, D. K., Sleep, N. H., and Bjerrum, C. J., 2010. No climate paradox under the faint early Sun: Nature, 464: 744-747. (doi:10.1038/nature08955)

Rudnick, R. L., 1995. Making continental crust. Nature, 378: 571-578.

Safronov, V.S., 1972. Evolution of the protoplanetary cloud and formation of the Earth and planets. NASA Technical Transactions, Washington DC, TTF-667.

Sclater, J.G., Jaupart, C., and Galson, D., 1980. The heat flow through the oceanic and continental crust and the heat loss of the earth. Reviews in Geophysics, 18: 269-312.

Schubert, G., and Reymer, A.P.S., 1985. Constant volume and freeboard through geologic time. Nature, 316: 336339.

Scherer, E. E., Whitehouse, M. J., and Münker, C., 2007. Zircon as a monitor of crustal growth. Elements, 3: 19-24.

Scholl, D. W., and von Huene, R., 2007. Crustal recycling at modern subduction zones applied to the past-Issues of growth and preservation of continental basement crust, mantle geochemistry, and supercontinent reconstruction. In: Hatcher, R. D., Jr., Carlson, M. P., McBride, J. H., Martínez. Catalán, (Eds.), 4-D Framework of Continental Crust. Geological Society of America Memoir 200: 9-32.

Scholl, D. W., and von Huene, R., 2009. Implications of estimated magmatic additions and recycling losses at the subduction zones of accretionary (non-collisional) and collisional (suturing) orogens: In: Cawood, P. A., Kröner, A., (Eds.), Accretionary Orogens. Geological Society of London Special Paper, 318: 105-125.

Scott, D.J, Helmstaedt, H., and Bickle, M.J., 1992. Purtuniq ophiolite, Cape Smith belt, northern Quebec, Canada: A reconstructed section of Early Proterozoic oceanic crust. Geology, 20: 173-176.

Şengör, A.M.C., Natal'in, B.A., Burtman, V.S., 1993. Evolution of the Altaid tectonic collage and Phanerozoic crustal growth in Eurasia. Nature 364, 299-307.

Şengör, A.M.C., Natal'in, B.A., 1996. Turkic-type orogeny and its rôle in the making of the continental crust. Annual Reviews of Earth Planetary Sciences 24, 263-337.

Shirey, S.B., and Richardson, S.H., 2011. Start of the Wilson cycle at 3Ga shown by diamonds from subcontinental mantle. Science, 333: 434-436.

Shirey, S.B., Richardson, S.H., and Harris, J.W., 2004. Integrated models of diamond formation and craton evolution. Lithos, 77: 923-944.

Shirey, S.B., Cartigny, P., Frost, D.J., Keshav, S., Nestola, F., Nimis, P., Pearson, D.G., Sobolev, N.V., and Walter, https://mc06.manuscriptcentral.com/cjes-pubs 
M.J., 2013. Diamonds and the geology of mantle carbon. Reviews in Mineralogy and Geochemistry, 75: 355-421. Shoemaker, E.M., 1984. Large body impacts through geologic time. Holland, H.D., Trendall, A.F. (Eds.), Patterns of Change in Earth Evolution. Dahlem Konferenzen 1984, Springer-Verlag, Berlin, 15-40.

Silver, P. G., and Behn, M. D., 2008. Intermittent plate tectonics? Science, 319: 85-88.

Sisson, T.W., Ratajeski, K., Hankins, W.B., and Glazner, A.F., 2004. Voluminous granitic magmas from basaltic sources. Contributions to Mineralogy and Petrology, 148: 635-661.

Sklyarov, E.V., Theunissen, K., Melnikov, A.I., Klerkx, J., Gladkochub, D.P., and Mruma, A., 1998. Paleoproterozoic eclogites and garnet pyroxenites of the Ubende Belt (Tanzania). Schweizerisches Mineralogische und Petrographische Mitteilungen, 78: 257-271.

Skublov, S.G., Berezin, A.V., and Mel'nik, A.E., 2011. Paleoproterozoic eclogites in the Salma Area, Northwestern Belomorian mobile belt: Composition and isotopic geochronologic characteristics of minerals and metamorphic age. Petrology, 19: 470-495.

Sleep, N.H., 1992. Archean plate tectonics: what can be learned from continental geology? Canadian Journal of Earth Sciences, 29: 2066-2071.

Sleep, N.H., 2000. Evolution of the mode of convection within terrestrial planets. Journal of Geophysical Research, 105: 17,563-17,578.

Sleep, N.H., 2005. Evolution of the continental lithosphere. Annual Reviews of Earth and Planetary Sciences, 33 : 369-393.

Sleep, N. H., 2007. Plate tectonics through time. Treatise on Geophysics, 9: 145-169.

Sleep, N.H., and Windley, B.F., 1982. Archean plate tectonics: constraints and inferences. Journal of Geology, 90: 363-379.

Sleep, N. H., and Bird, D. K., 2007. Niches of the pre-photosynthetic biosphere and geologic preservation of Earth's earliest ecology. Geobiology, 5: 101-117. (doi:10.1111/j.1472-4669. 2007.00105.x)

Sleep, N.H., Zahnle, K., and Neuhoff, P.S., 2001. Initiation of clement surface conditions on the earliest Earth. Proceedings of the National Academy of Sciences, 98: 3666-3672.

Sleep, N. H., Zahnle. K. J., and Lupur, R. E., 2014. Terrestrial aftermath of the Moon-forming impact. Philosophical Transactions of the Royal Society, A372, http://dx.doi.org/10.1098/rsta.2013.0172

Smith, D.C., 1984. Coesite in clinopyroxene in the Caledonides and its implications for geodynamics. Nature, 310 : 641-644.

Smith, J.V., 1981. The first 800 million years of earth's history. Philosophical Transactions of the Royal Society of London, 301A: 401-422.

Smithies, R.H., Champion, D.C., and Cassidy, K.F., 2003. Formation of Earth's Early Archean continental crust. Precambrian Research, 127: 89-101.

Smithies, R.H, Champion, D.C., Van Kraenendonk, M.J., Howard, H.M., and Hickman, A.H., 2005a. Modern-style subduction processes in the Mesoarchaean: geochemical evidence from the $3.12 \mathrm{Ga}$ Whundo intra-oceanic arc. Earth and Planetary Science Letters, 231: 221-237. 
Smithies, R. H, Van Kraenendonk, M.J., and Champion, D. C., 2005b. It started with a plume-Early Archaean basaltic proto-continental crust. Earth and Planetary Science Letters, 238: 284-297.

Smithies, R.H., Van Kranendonk, K., and Champion, D.C., 2007. The Mesoarchean emergence of modern-style subduction. Gondwana Research, 11: 50-68.

Sobolev, N.V., and Shatsky, V.S., 1990. Diamond inclusions in garnets from metamorphic rocks. Nature, 343: 742746.

Šrámek, O., McDonough, W. F., and Learned, J. G., 2012. Geoneutrinos. Advances in High Energy Physics, Article ID 235686, 34p, doi:10.1155/2012/235686.

Šrámek, O., McDonough, W. F., Kite, E. S., Lekić, V., Dye, S. T., and Zhong, S., 2013. Geophysical and geochemical constraints on geoneutrino fluxes from Earth's mantle. Planetary Science Letters, 361: 356-366, doi: 10.1016/j.eps1.2012.11.001.

Stern, R.J., 2002. Subduction Zones. Reviews of Geophysics, 10.1029/2001RG000108.

Stern, R.J., 2005. Evidence from ophiolites, blueschists, and ultrahigh-pressure metamorphic terranes that the modern episode of subduction tectonics began in Neoproterozoic time. Geology, 33: 557-560.

Stern, R. J., 2007. When and how did plate tectonics begin? Theoretical and empirical considerations. Chinese Science Bulletin, 52: 578-591.

Stern, R. J., 2008. Modern-style plate tectonics began in Neoproterozoic time: An alternative interpretation of Earth's tectonic history. In Condie, K.C., and Pease, V. (Eds.), When Did Plate Tectonics Begin on Earth? Geological Society of America Special Paper 440: 265-280.

Stevenson, D.J., 1983. The nature of the Earth prior to the oldest known rock record: the Hadean Earth. In: Schopf, J.W. (Ed.), The Earth's earliest Biosphere: Its Origin and Evolution. Princeton University Press, Princeton, 32-40.

Stevenson, D.J., 2003. Styles of mantle convection and their influence on planetary evolution. Comptes Rendus Geoscience, 335: 99-111.

Stolper, E., Walker, D., Hagar, B., and Hays, J., 1981. Melt segregation from partially molten source regions: the importance of melt density and source region size. Journal of Geophysical Research, 86: 6261-6271.

Szilas, K., Hoffmann, J.E., Scherstén, A., Rosing, M.T., Windley, B.F., Kokfelt, T.F., Keulen, N., van Hinsberg, V.J., Næraa, T., Frei, R., Carsten Münker, C., 2012. Complex calc-alkaline volcanism recorded in Mesoarchaean supracrustal belts north of Frederikshåb Isblink, southern West Greenland: Implications for subduction zone processes in the early Earth. Precambrian Research 208-211, 90- 123.

Tackley, P., 2000. Self-consistent generation of plate tectonics in time-dependent, three-dimensional mantle convection simulations, 1. pseudoplastic yielding. Geochemistry, Geophysics, Geophysics, Geosystems 1. $2000 \mathrm{GC} 000036$.

Tarduno, J.A., Cottrell, R.D., Davis, W.J., Nimmo, F., Bono, R.K., 2015. A Hadean to Paleoarchean geodynamo recorded by single zircon crystals. Science, 349: 6247, 521-524.

Tatsumi, Y., 2000. Slab melting: Its role in continental crust formation and mantle evolution. Geophysical Research Letters, 27: 3941-3944.

Tatsumi, Y., 2005. The subduction factory: How it operates in the evolving Earth. GSA Today, 15, no. 7: 4-10. 
Taylor, S.R., 1992. Solar System Evolution. Cambridge University Press, New York.

Taylor, S.R., and McLennan, S.M., 1985. The Continental Crust: Its Composition and Evolution. Blackwell Press, Oxford.

Tolich, N., 2012. Geo-neutrino review. Nuclear Physics B (Proc. Suppl.) 229-232: 407-411.

Trail, D., Mojzsis, S. J., Harrison, T. M., Schmitt, A. K., Watson, E. B., and Young, E. D., 2007. Constraints on Hadean zircon protoliths from oxygen isotopes, Ti-thermometry, and rare earth elements. Geochemistry Geophysics Geosystems, 8: Q06014, doi: 10.1029/2006GC001449.

Tsujimori, T., and Ernst, W. G., 2014. Lawsonite blueschists and lawsonite eclogites as proxies for paleo-subduction zone processes. Journal of Metamorphic Geology, 32: 437-454, doi:10.1111/jmg.12057.

Turcotte, D.L., and Kellogg, L.H., 1986. Isotopic modeling of the evolution of the mantle and crust. Reviews in Geophysics, 24: 311-328.

Turcotte, D.L., and Schubert, G., 1982. Geodynamics. John Wiley, New York.

Turner, S., Rushmer, T., Reagan, M., and Moyen, J.-F., 2014. Heading down early on? Start of subduction on Earth. Geology, 42: 139-142.

Tsuchiya, T., Kawai, K., Maruyama, S., 2013. Expanding-contracting Earth. Geoscience Frontiers, 4: 341-347.

Ulmer, P., 2001. Partial melting in the mantle wedge - the role of $\mathrm{H}_{2} \mathrm{O}$ in the genesis of mantle-derived 'arc-related' magmas. Physics of the Earth and Planetary Interiors, 127: 215-232.

Valencia, D., O’Connell, R.J., and Sasselov, D.D., 2007. Inevitability of plate tectonics on super-Earths. Icarus, Astrophysical Journal, 670: L45-L48.

Valley J.W., 2015. Time's arrow and time's cycle. Elements, 11: 83-84.

Valley, J.W., Peck, W.H. , King, E.M., and Wilde, S.A., 2002. A cool early Earth, Geology. 30: 351-354.

Valley, J.W., Lackey, J.S., Cavosie, A.J., Clenchenko, C.C., Spicuzza, M.J., Basei, M.A.S., Bindeman, I.N., Ferreira, V.P., Sial, A.N., King, E.M., Peck, W.H., Sinha, A.K., and Wei, C.S., 2005. 4.4 billion years of crustal maturation: oxygen isotope ratios of magmatic zircon. Contributions to Mineralogy and Petrology, 150: 561-580.

Van Kranendonk, M.J., Collins, W.J., Hickman, A., Pawley, M.J., 2004. Critical tests of vertical vs horizontal tectonic models for the Archaean East Pilbara granite-greenstone terrane, Pilbara craton, western Australia. Precambrian Research, 131: 173-211.

Veizer, J., 1976. ${ }^{87} \mathrm{Sr} /{ }^{86} \mathrm{Sr}$ evolution of seawater during geologic history and its significance as an index of crustal evolution. In: Windley, B.F. (Ed.), The Early History of the Earth. John Wiley, New York, 569-578.

Voice, P.J., Kowalewski, M., and Eriksson, K.A., 2011. Quantifying the time and rate of crustal evolution: Global compilation of radiometrically dated detrital zircon grains. Journal of Geology, 119: 109-126.

Volodichev, O.I., Slabunov, A.I., Bibikova, E.V., Konilov, A.N., and Kuzenko, T.I., 2004. Archean eclogites in the Belomorian Mobile Belt, Baltic Shield. Petrology, 12: 609-631.

von Huene, R., and Scholl, D.W., 1991. Observations at convergent margins concerning sediment subduction, subduction erosion, and the growth of continental crust. Reviews of Geophysics. 29: 279-316.

Wang, J.P., Kusky, T.M., Polat, A., Wang, L. Deng, H., Wang, S., 2013. A late Archean tectonic mélange in the Central Orogenic Belt, North China Craton. Tectonophysics 608, 929-946. 
Wanke, H., Dreibus, G., and Jagoutz, E., 1984. Mantle geochemistry and accretion history of the Earth. In: Kröner,

A., Hanson, G.N., Goodwin, A. M. (Eds.), Archean Geochemistry. Springer-Verlag, Berlin, 1-24.

Watson, E.B., and Harrison, T.M., 2005. Zircon thermometer reveals minimum melting conditions on earliest Earth.

Science, 308: 841-844.

Westerlund, K.J., Shirey, S.B., Richardson, S. H., Carlson, R. W., Gurney, J.J., Harris, J.W., 2006. A

subduction wedge origin for Paleoarchean peridotitic diamonds and harzburgites from the Panda

kimberlite, Slave craton: evidence from Re-Os isotope systematics. Contributions to Mineralogy and

Petrology, 152: 275-294.

Wetherill, G.W., 1976. The role of large bodies in the formation of the Earth and Moon. Proceedings of the Lunar

Science Conference, 7: 3245-3257.

Wetherill, G.W., 1988. Formation of the earth. In: Osterbrock, D.E., Raven, P.H. (Eds.), Origins and Extinctions. Yale

University Press, New Haven, 43-82.

Wetherill, G.W., 1990. Formation of the Earth. Annual Reviews of Earth and Planetary Sciences, 18: 205-256.

Wilde, S.A., Valley, J.W., Peck, W.H., and Graham, C.M., 2001. Evidence from detrital zircons for the existence of continental crust and oceans on the Earth 4.4 Ga ago. Nature, 409: 175-178.

Williams, H., Hoffman, P.F., Lewry, J.F., and James, N.P., 1991. Anatomy of North America: thematic geologic portraits of the continent. Tectonophysics, 187: 117-134.

Williams, I. S., 2007. Old diamonds and the upper crust. Nature, 448: 880-881.

Windley, B.F., 1995. The Evolving Continents. $3^{\text {rd }}$ edition. John Wiley and sons, New York, 526p.

Wilson, J. T., 1968. Static or mobile earth: the current scientific revolution. Proceedings of the American

Philosophical Society, 1968: 303-320.

Wyman, D.A., Kerrich, R., and Polat, A., 2002. Assembly of Archean cratonic mantle lithosphere and crust: Plume-

arc interaction in the Abitibi-Wawa subduction-accretion complex. Precambrian Research, 115: 37-62.

Wyllie, P.J., 1979. Magmas and volatile components. American Mineralogist, 64: 469-500.

Wyllie, P.J., 1981. Plate tectonics and magma genesis. Geologische Rundschau, 70: 128-153.

Yuen, D.A., Maruyama, S., Karato, S.I., Windley, B. F., 2007. Superplumes: Beyond Plate Teconoics. Springer, Dordrecht, The Netherlands, 569p.

Zahnle, K., Arndt, N., Cockell, C., Halliday, A., Nisbet, E., Selsis, F., and Sleep, N. H., 2007. Emergence of a habitable planet. Space Science Reviews, 129: 35-78.

\section{FIGURE CAPTIONS}

Fig. 1. Experimentally determined P-T melting curves for fertile peridotite, dry and with minor $\mathrm{H}_{2} \mathrm{O}$ or $\mathrm{CO}_{2}$ and of granite, dry and with minor or excess $\mathrm{H}_{2} \mathrm{O}$ (Luth et al. 1964; Ito and Kennedy 1967; Lambert and Wyllie 1972; Wyllie 1979, 1981; Presnall and Gudfinnsson 2005). The $\mathrm{H}_{2} \mathrm{O}$-saturated solidus of basalt lies $\sim 200{ }^{\circ} \mathrm{C}$ above that of wet granite (Hill and Boettcher 1970; Poli and Schmidt 1995; Liu et al. 1996). The diamond-graphite phase-equilibrium P-T curve is from Kennedy and Kennedy (1976). Modern intraplate suboceanic and subcratonal geothermal gradients (Clark and Ringwood,1964), and a 
3.6 Ga geothermal gradient assuming $\sim 300 \%$ of the modern radiogenic heat production in a stratified Archean mantle are illustrated (Lambert 1976; Richter 1988; Pollack 1997).

Fig. 2. Schematic diagram of competing crustal generation and mantle return (i.e., subduction transportation + subcrustal erosion) of juvenile calcalkaline rocks attending mantle-crust differentiation, illustrating net accumulation of sialic material over geologic time (e.g., Jacobsen and Wasserburg 1981; Ernst 1983; DePaolo et al. 1991; Condie 1998, 2007; Condie and Kröner 2013). In (a), net preservation of continental crust is assumed to be a smoothly changing function of planetary cooling. In (b), episodes of rapid overturn and greater loss of continental crust due to viscous coupling is conjectured to have preceded by $\sim 100 \mathrm{Myr}$ the high rates of calcalkaline igneous arc activity and consequent high rates of formation of granitic crust at 3.5?, 2.7, 2.0, and 1.1 Ga. For a quantitative synthesis of global growth rates of continental crust, see O’Neil et al. (2007, fig. 1), Valley (2015, fig. 1) and Figure 5.

Fig. 3. Petrogenetic grid for rocks of basaltic bulk composition, after Liou et al. (1998) and Okamoto and Maruyama (1999). The 3.6 Ga early Earth geothermal gradient is from Figure 1. Phanerozoic P-T paths for outboard Pacific-type (high-P) and Alpine-type (UHP) underflow and collision are from Ernst (2007); an Archean subduction zone P-T trajectory would lie at a considerably higher T for a given P (Brown 2006, 2007, 2008). For comparison, P-T estimates of various subduction-collisional metamorphic rocks from Neoproterozoic + younger, and Mesoproterozoic + older orogens (Komiya et al. 2002; Maruyama and Liou 2005) are also shown. A very low-T (e.g., Phanerozoic) subductionzone geothermal gradient of $5^{\circ} \mathrm{C} / \mathrm{km}$ and a $20^{\circ} \mathrm{C} / \mathrm{km}$ are shown for reference. Citations to experimental phase equilibria are in Liou et al. (1998). Mineral abbreviations: Dia = diamond; $\mathrm{Gr}=$ graphite; Tlc = talk; Gln = glaucophane; $\mathrm{Jd}=$ jadeite; $\mathrm{Qz}=$ quartz; $\mathrm{Ab}=$ albite. Metamorphic-facies abbreviations: $\mathrm{AM}=$ amphibolite; Amp-EC = amphibolite-eclogite; $\mathrm{BS}=$ blueschist; $\mathrm{EA}=$ epidote amphibolite; EC = eclogite; Ep-EC = epidote-eclogite; GR = sillimanite-granulite; GS = greenschist; HGR = kyanite-granulite; Lw-EC = lawsonite-eclogite. Weakly recrystallized rocks of the zeolite, prehnite, pumpellyite-actinolite, and prehnite-pumpellyite subfacies (not illustrated) lie at lower P-T values than GS and BS.

Fig. 4. Evolving proportions of superjacent layered rocks preserved in the geologic record as a function of age, after Ronov and Migdisov (1971) and Condie (1982). For additional estimates of granitic crustal generation, see McCulloch and Bennett (1994) and Condie (1998). BIF = banded iron formation. Due to episodic production \pm preservation of sialic material over time, such smoothly varying accumulation curves are only approximations to the growth of the upper crust (see Fig. 2).

Fig. 5. Diagram depicting evolution of the sialic crust (see also Valley 2015, fig. 1) based on compiled detrital zircon U-Pb ages ( $\leq 5 \%$ discordant filtered) in the Global Detrital Zircon Database-GDZDbof Voice et al. (2011), metamorphic-facies types as a function of geothermal gradients (Brown 2007), 
ophiolite ages (Dilek 2003), and times of supercontinental assembly (Bradley 2011; Cawood et al. 2013; Condie et al. 2015). Arrow shows age of oldest well-documented ophiolite complex (Peltonen and Kontinen 2004). Times of the breakups of Superia and Sclavia may be as young as $\sim 2.3$ and $\sim 2.1$ $\mathrm{Ga}$, respectively.

Fig. 6. Schematic, transitional stages in evolution of the terrestrial crust-mantle system, after Ernst (2007). For simplicity, we invoke-mantle convection but do not specify sizes or morphologies of cells. French and Romanowicz (2015) provide tomographic indications of present-day circulating cells in the upper $1000 \mathrm{~km}$ of the planet, whereas Tsuchiya et al (2013) posit double-layer convection prior to about 2.6Ga (see also Yuen et al. eds. 2007). Oceanic crust is shown in dark green, continental crust in pink. Increasing thicknesses with time of lithospheric plates are exaggerated for clarity. Early advective heat transport chiefly by at least episodic - if not continuous - bottom-up asthenospheric mantle convection + plume ascent, is indicated in red-orange. Over time, thickening, enlarging oceanic lithospheric plates and chemically-mineralogically buoyant cratonal lids began to dominate mantle overturn through topdown oceanic slab descent. At times, asthenospheric convection was generated beneath chemically buoyant stagnant-lid lithosphere following supercontinental accretion; thermal build-up in the subcontinental mantle thus caused rifting and supercontinent dispersal, as shown in stage c. See text for discussion. 


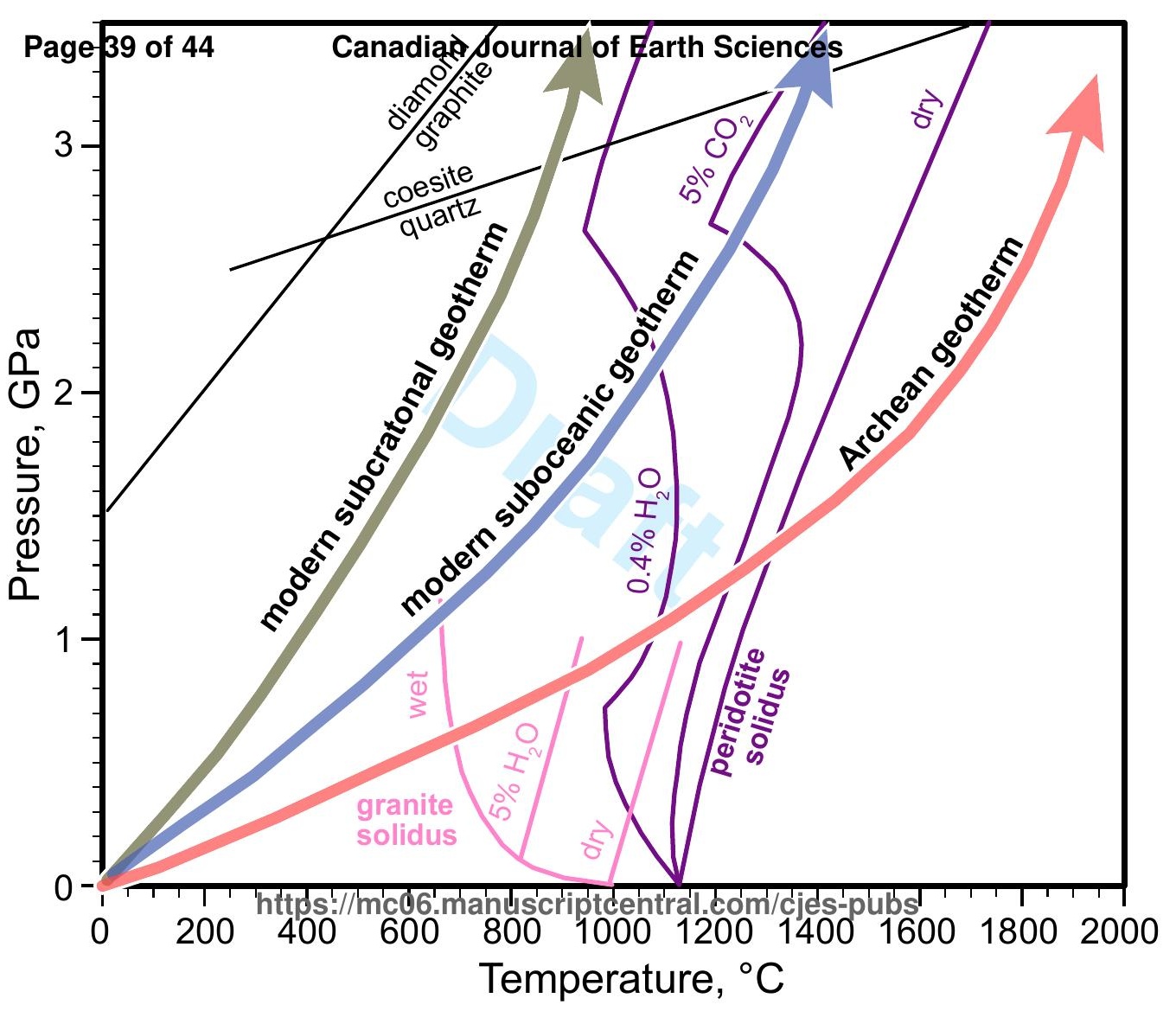




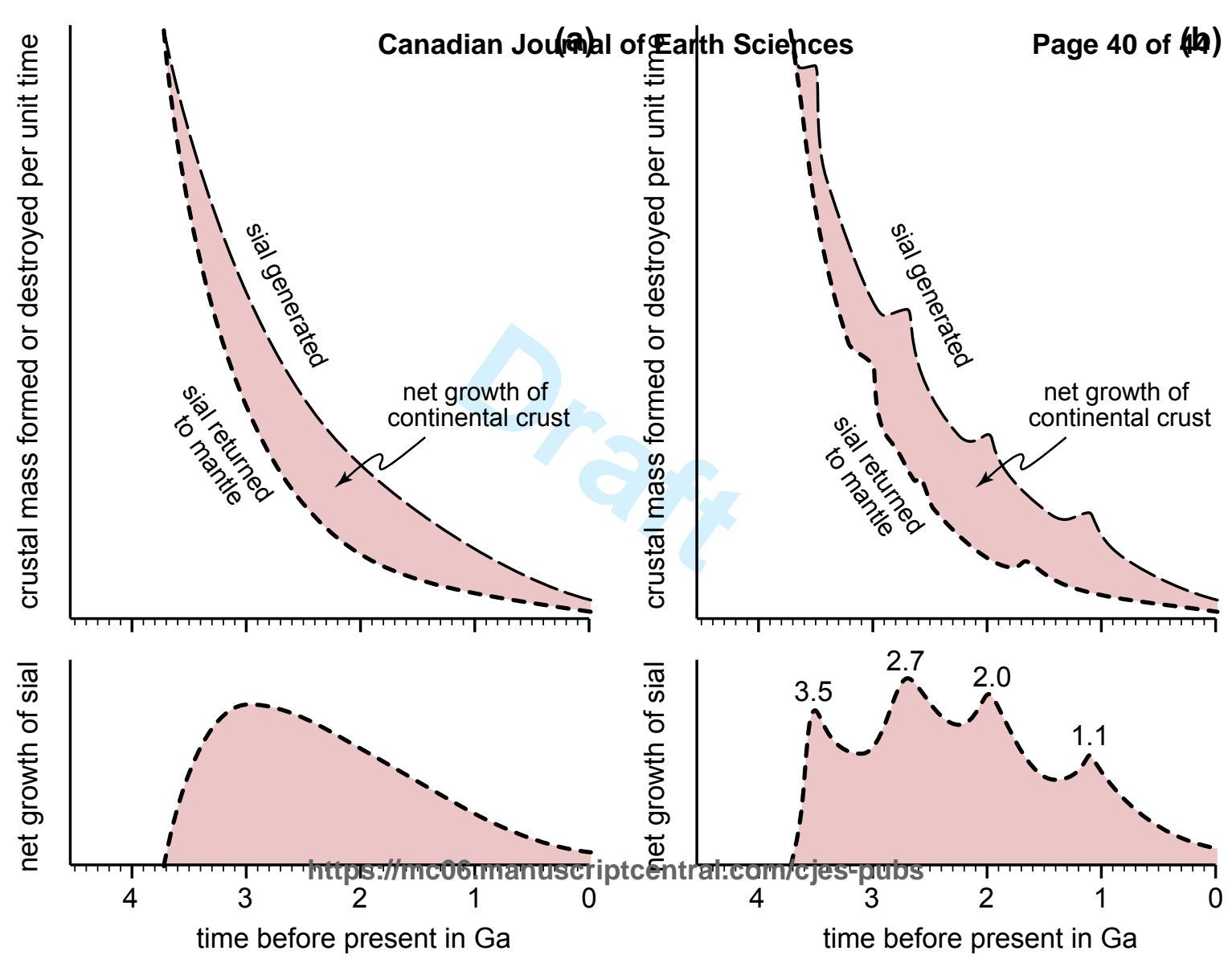




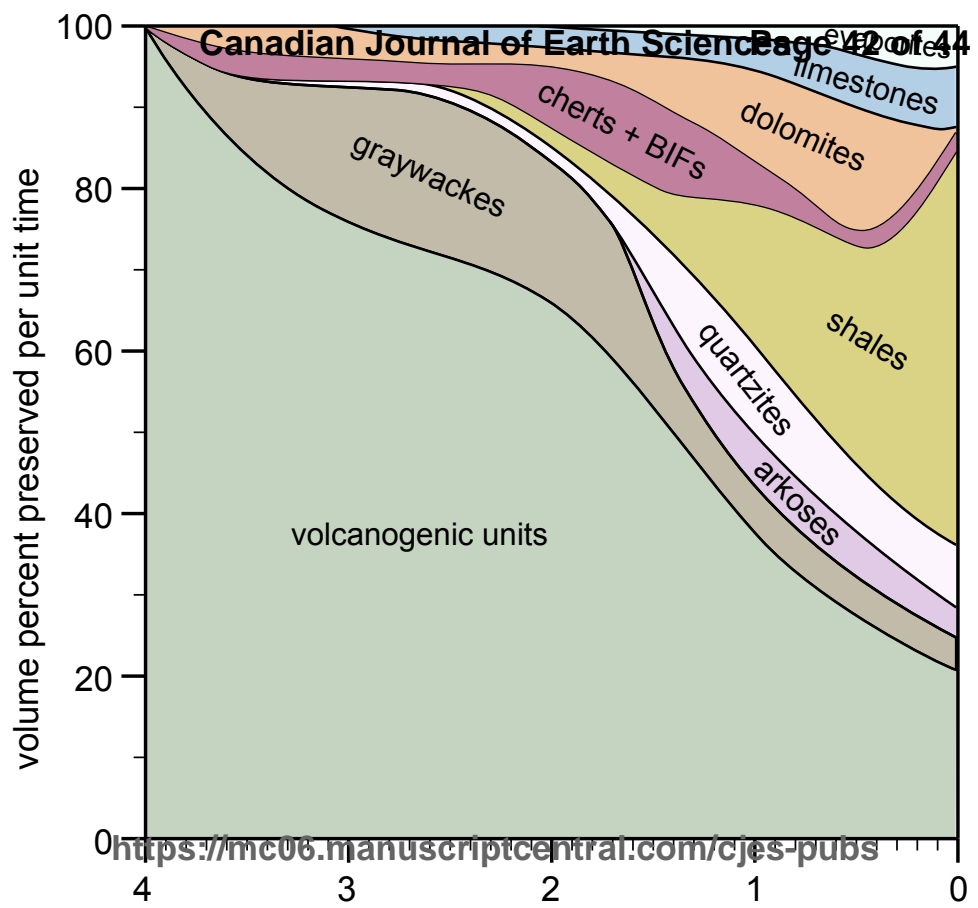

time before present in $\mathrm{Ga}$ 


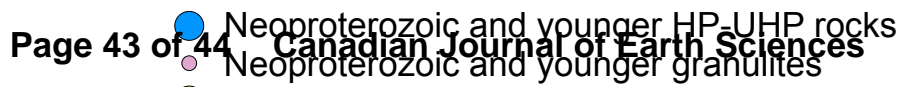

Mesoproterozoic and older HP rocks and granulites

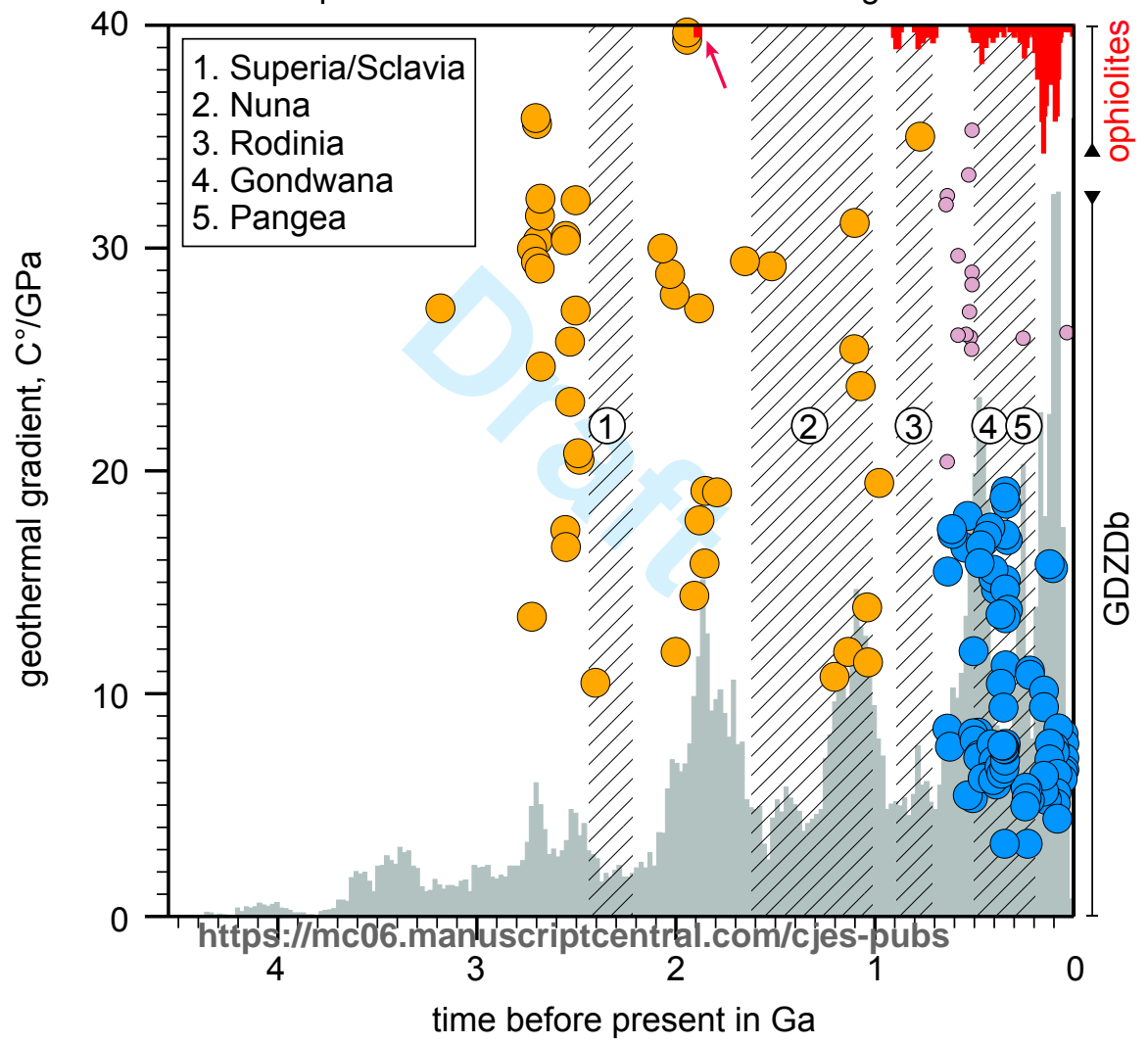




\section{(b) platatatian Journal of Earth Sciences}

\section{4-2.7 Ga}

(c) supercontinental

(a) pre-plate 4.5-4.4 Ga

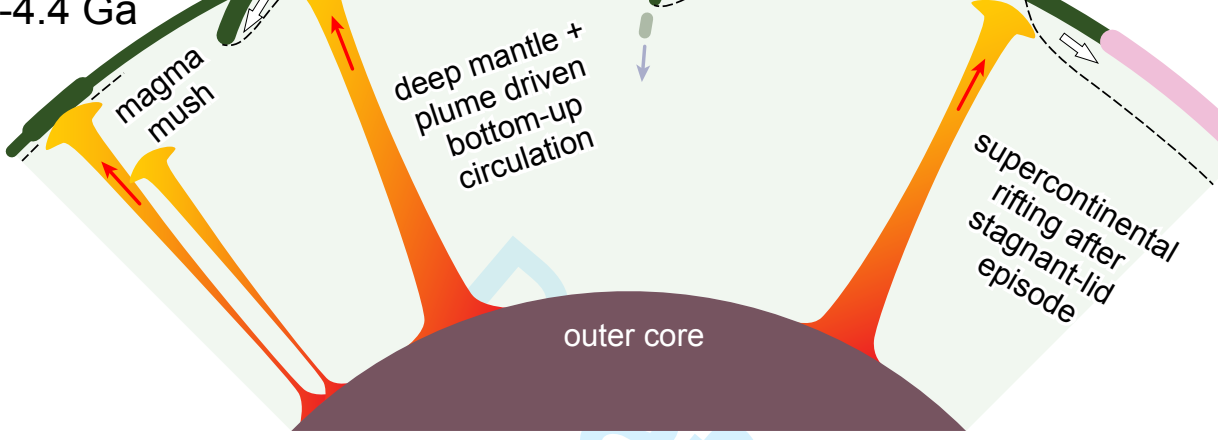

$2.7-1.0 \mathrm{Ga}$

(d) Wilson cycle

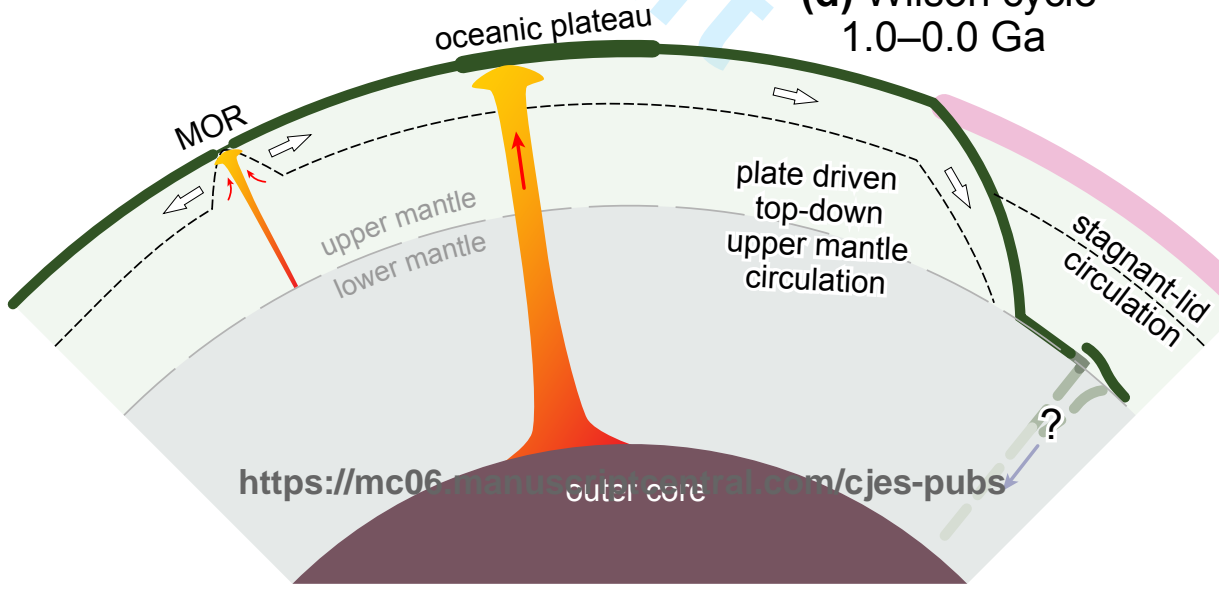

